\title{
O DESVIO DE PODER
}

RAFAel MUNHOZ DE Mello'

\begin{abstract}
Introdução - 1. Função administrativa e finalidade: 1.1. A função administrativa; 1.2. A finalidade como elemento do ato administrativo - 2. $O$ vício do desvio de poder: 2.1. Recapitulação; conceito de desvio de poder; 2.2. Origem histórica; 2.2.1. França e Itália; 2.2.2. A origem do desvio de finalidade no Brasil; 2.3. Configuração do desvio de poder; 2.3.1. Considerações preliminares; 2.3.2. Natureza do desvio de poder; 2.3.3. Modalidades do desvio de poder; 2.3.4. O problema da intencionalidade do agente; 2.4. A prova do desvio de poder - Conclusão - Referências bibliográficas.
\end{abstract}

\section{Introdução}

O desvio de poder é, dentre os vícios do ato administrativo, aquele que apresenta maior complexidade. De fato, tratando-se de desvio de poder todo tipo de dificuldade aflora, desde sua natureza até a prova de sua ocorrência no agir da Administração Pública.

Acresce que o desvio de poder está intimamente relacionado aos temas mais basilares do direito administrativo, e, bem por isso, dotados também de intensa complexidade. Impossível, com efeito, analisar o desvio de poder sem que se tenha nítida a noção de função administrativa e de discricionariedade, sem mencionar o tormentoso tópico da invalidade dos atos administrativos.

Não obstante a dificuldade do tema, justifica-se seu estudo em decorrência do triste fato de ser o desvio de poder praticado cotidianamente pelos agentes públicos, em maior ou menor grau, seja nas altas esferas governamentais da União Federal, seja no mais baixo escalão da hierarquia administrativa dos municípios.

Inexplicavelmente, aliás, apesar de sua importância, poucas são as obras no direito administrativo pátrio dedicadas ao tema, fato que pode explicar a igualmente

1 Mestrando em Direito Administrativo na Pontifícia Universidade Católica de São Paulo. Advogado em Curitiba.

R. Dir. Adm.,

Rio de Janeiro, 228: 31-66,

Abr./Jun. 2002 
pequena aplicação jurisprudencial do desvio de finalidade como forma de controle dos atos administrativos.

Sem outra pretensão que não a de expor os caracteres jurídicos do desvio de poder. o presente estudo parte justamente da função administrativa e de sua relação com a finalidade legal (capítulo primeiro), passando em seguida aos elementos que configuram o vício ora em exame (capítulo segundo).

\section{Função administrativa e finalidade}

\subsection{A função administrativa}

Reza a Constituição Federal de 1988, já em seu art. $1^{\circ}$, parágrafo único, que "todo o poder emana do povo, que o exerce por meio de representantes eleitos ou diretamente, nos termos desta Constituição".

Trata-se de princípio caracterizador de um Estado Democrático de Direito, segundo o qual é o povo o titular do poder estatal e, ademais, personagem participativo da formação da vontade estatal, seja diretamente, seja através de representantes eleitos. ${ }^{2}$

Ainda que seja o povo o titular do poder estatal, o exercício de tal poder é em regra atribuído a órgãos estatais, na forma como o próprio povo estabelecer através do poder constituinte. O povo, portanto, atribui o exercício de diferentes funções estatais a determinados órgãos, que no limite da sua competência têm autonomia para exercê-las, sem subordinação aos demais entes estatais.

O conceito de função é de grande relevância para a compreensão do fenômeno do exercício do poder estatal. Consiste a função num plexo de poderes atribuído a determinado ente para que sejam tutelados interesses alheios. É dizer, quem exerce função busca a satisfação de interesses que não os próprios, mas sim de terceiros, através da utilização dos poderes que lhe são conferidos para tal fim. Veja-se a lição de Celso Antônio Bandeira de Mello:

2 José Afonso da Silva anota que "o Estado Democrático de Direito reúne os princípios do Estado Democrático 'c do Estado de Direito, não como simples reunião formal dos respectivos elementos, porque, em verdade, revela um conceito novo que os supera, na medida em que incorpora um componente revolucionário de transformação do status quo" (Curso de direito constitucional positivo, p. 116). Assim, num Estado Democrático de Direito também estão presentes os princípios do Estado Liberal de Direito, que surge com as revoluções burguesas dos séculos XVII e XVIII, a saber: submissão do Estado ao ordenamento jurídico, separação de poderes entre órgãos distintos e garantia de direitos individuais. Cite-se a lição de Fausto Cuocolo: "Stato di diritto è quello nel quale non solo ogni autorità è subordinatà al diritto, ma il diritto ha determinati contenuti, riconoscendosi ai cittadini le libertà civili e diritti pubblici subiettivi esperibili e tutelabili giurisdizionalmente anche nei confronti dello Stato" (Istituzioni di diritto pubblico, p. 92). 
Existe função quando alguém está investido no dever de satisfazer dadas finalidades em prol de interesses de outrem, necessitando, para tanto, manejar os poderes requeridos para supri-las. Logo, tais poderes são instrumentais ao alcance das sobreditas finalidades. Sem eles, o sujeito investido na função não teria como desincumbir-se do dever posto a seu cargo. Donde, quem os titulares maneja, na verdade, 'deveres-poderes', no interesse alheio. ${ }^{3}$

Os entes estatais exercem função. E nem poderia ser diferente, ao menos após a derrocada do Estado Absolutista. Afinal, se o poder pertence ao povo, que delega seu exercício a determinados órgãos, natural que estes o utilizem visando ao atendimento dos interesses do próprio povo. É com tal finalidade que ocorre a mencionada delegação, e não para que os agentes estatais utilizem o poder que thes é conferido em interesse próprio, como se dele fossem titulares. Não o são, como visto. $^{4}$

Dito isso, é preciso que se investigue quais são as funções estatais. A classificação clássica é a que identifica três diferentes funções: legislativa, jurisdicional e administrativa. ${ }^{5}$ Não serão estudadas, aqui, as diversas críticas encontradas na doutrina sobre a tripartição, pois o tema escapa dos limites e pretensões do presente trabalho. ${ }^{6}$ Independentemente das críticas, adotar-se-á a tripartição clássica, em virtude de sua importância histórica, que a consagrou no pensamento do direito público, ${ }^{7}$ e também em função de estarem as atividades legislativa, jurisdicional e administrativa presentes em todo e qualquer Estado, ${ }^{8}$ como bem notou o jurista italiano Biscaretti di Ruffia:

3 Curso de direito administrativo, p. 32.

4 Daí afirmar Ruy Cirne Lima, ao tratar da função administrativa: "administração, segundo o nosso modo de ver, é a atividade do que não é o proprietário - do que nāo tem a disposição da cousa ou do negócio administrado" (Princípios de direito administrativo, p. 22).

5 Já em Aristóteles é possível encontrar os traços dessa tripartição de funções (A política, p. 238). Foi Montesquieu, todavia, que propugnou pela separação das três funções entre órgãos distintos, ao reconhecer que "todo se habría perdido si el mismo hombre, la misma corporación de próceres, la misma asamblea del pueblo ejerciera los tres poderes: el de dictar las leyes; el de ejecutar las resoluciones públicas y el de juzgar los delitos y los pleitos entre particulares" (El espiritu de las leyes, pp. 149-151).

6 Sobre o tema, ver em especial Francis-Paul Bénoit, Le droit administratif français, pp. 27-52. Ver ainda um apanhado dos diversos autores que dirigiram suas críticas à tripartição clássica em Clèmerson Merlin Clève, Atividade legislativa do poder executivo, pp. 31-34.

7 Tratando das críticas formuladas à tripartição clássica das funções estatais, ensina Balladore Pallieri: "Le obbiezioni del Kelsen e degli altri molti che con lui concordano, perdono ogni valore ove si tenga invece presente che quella tripartizione, se non ha un fondamento logico, ne ha invece uno storico rilevantissimo" (Diritto costituzionale, p. 82).

8 É verdade que há atividades estatais que não se enquadram em nenhuma das funções estatais clássicas. Não é menos verdade, entretanto, que a grande maioria dos atos praticados pelo Estado pode ser classificada como manifestação da função legislativa, jurisdicional ou administrativa, circunstância que torna útil a tripartição ora adotada. Deve-se ter em mente, todavia, que há exceçōes, as quais devem ser tratadas como tal. 
L'esposta tripartizione presenta un valore universale: in quanto anche in uno Stato a governo assoluto, in cui tutte le funzioni statali facciano capo ad un solo organo, purtuttavia, concettualmene, esse resteranno sempre differenziabili. ${ }^{9}$

Adotando-se a tripartição das funções estatais - legislativa, jurisdicional e administrativa - surge então novo problema: como distingui-las? Há, para tanto, três critérios: orgânico, material e formal.

O critério orgânico utiliza como elemento de discriminação o órgão que pratica a atividade. A função legislativa, assim é a exercida pelo Poder Legislativo, a jurisdicional pelo Poder Judiciário, e a administrativa pelo Poder Executivo.

Já o critério material distingue as funções segundo a natureza da atividade praticada no seu exercício. É irrelevante, aqui, o órgão que emana o ato; relevante é a natureza do próprio ato. De acordo com o critério material, a função legislativa consiste na edição de leis, entendidas como normas gerais e abstratas. ${ }^{10} \mathrm{~A}$ função jurisdicional, por sua vez, é a atividade de solução de conflitos de interesses (lides) através da aplicação do direito ao caso concreto. E a função administrativa, por fim, é a atividade pela qual o Estado atende, de modo concreto e individual, os fins que lhe são próprios.

Nenhum dos dois critérios mencionados serve para um estudo jurídico do tema das funções estatais. Ao jurista há um único elemento de distinção relevante: o regime jurídico. E os critérios orgânico e material não permitem que atividades exercidas sob um mesmo regime jurídico sejam agrupadas sob uma mesma função estatal, ou pior, consideram como manifestação de uma mesma função atividades que, sob o enfoque do regime jurídico, diferem completamente.

Dois exemplos bastam para demonstrar a inaptidão dos critérios apontados para a ciência do direito. $O$ critério material não permite que se distinga a edição de uma lei ordinária pelo Parlamento da edição de um regulamento pela Administração Pública, pois nos dois casos há norma geral e abstrata, e, portanto, função legislativa. Já o critério orgânico coloca sob um mesmo rótulo a criação da lei ordinária e a demissão de funcionário integrante da estrutura da Câmara dos Deputados, pois lá e cá o órgão é o mesmo: Poder Legislativo.

Resta, portanto, o critério formal, que é justamente o que considera como traço de distinção entre as funções estatais o regime jurídico peculiar de cada qual. Nesse sentido pode-se dizer, na esteira do pensamento de Francis-Paul Bénoit, que "une fonction est alors un ensemble de missions exercées selon un même régime". ${ }^{11}$

$O$ regime jurídico da função legislativa caracteriza-se pela possibilidade de inovação primária da ordem jurídica e consequiente derrogação de disposições em contrário, com submissão tão-somente ao texto constitucional. A função jurisdicio-

9 Diritto costituzionale, p. 153.

10 "La loi d'abord est une règle générale; et toute disposition qui n'a pas ce caractère n'est pas une loi, même si elle est édictée par un prétendu souverain" (Léon Duguit, L'État, p. 502).

11 Ob. cit., p. 40. 
nal, por seu turno, tem seu regime jurídico peculiarizado pela ocorrência da coisa julgada, que torna imutável as decisões proferidas no curso de processo judicial. ${ }^{12}$

A função administrativa, por sua vez, também tem seu peculiar regime jurídico, que a difere das demais funções estatais. É a especial submissão à lei formal ${ }^{13}$ que caracteriza a função administrativa, diversa da submissão imposta aos órgãos estatais que exercem as demais funções.

Com efeito, num Estado de Direito todos os entes estatais submetem-se ao ordenamento jurídico. ${ }^{14}$ Trata-se do princípio da legalidade, que impõe aos próprios agentes estatais a observância das normas jurídicas.

Aos órgãos que exercem função administrativa também se aplica o princípio da legalidade, mas com uma peculiaridade: tais órgãos não só devem respeito ao ordenamento jurídico, mas somente podem agir quando expressamente autorizados por lei formal. No silêncio da lei não pode a Administração Pública agir; sem autorização legal não há espaço para o exercício da função administrativa. Daí a lição de Hely Lopes Meirelles: “enquanto na administração particular é lícito fazer tudo que a lei não proíbe, na Administração Pública só é permitido fazer o que a lei autoriza". ${ }^{15}$

A lei formal, editada no exercício da função legislativa, outorga competência aos órgãos que compõem a Administração Pública. A regra de competência pode disciplinar em maior ou menor grau a atividade administrativa, mas sempre o faz, fixando formas, motivos, finalidades, etc. Os atos praticados no exercício da função administrativa somente são lícitos, e portanto válidos, se observarem fielmente a regra de competência editada pelo legislador. ${ }^{16}$ Valem ser transcritas, a propósito, as seguintes palavras de Eduardo García de Enterría:

12 Oswaldo Aranha Bandeira de Mello, Princípios gerais de direito administrativo, p. 23.

13 Ao conceito de lei formal é irrelevante o órgão que edita a norma e o seu conteúdo. Importante é o regime jurídico: possibilidade de inovação primária da ordem jurídica, com submissão ao texto constitucional. Ou seja, lei formal é o ato praticado no exercício da função legislativa. Ou, nas palavras sempre autorizadas de Seabra Fagundes, é "todo ato emanado das entidades às quais a Constituição atribua função legislativa" ( $O$ controle dos atos administrativos pelo Poder Judiciário, 1967, pp. 34-35).

14 “É sabido que princípio característico e essencial do Estado de Direito é precisamente o de que o Estado se comporta em relação aos particulares na forma do direito, quere dizer, ligado pelas normas jurídicas, qualquer que seja sua fonte; e que, diversa e opostamente, no Estado-Polícia a atividade do Estado, incluindo aquela que está em imediata relação com os particulares, não se encontra sujeita, vinculada a qualquer norma juridica de que os mesmos particulares possam exigir o cumprimento" (Afonso Rodrigues Queiró, A teoria do desvio de poder em direito administrativo, RDA vol. VI, p. 41).

15 Direito administrativo brasileiro, p. 82.

16 "Les organes administratifs, obligés en raison de leur compétence d'appliquer la loi, ne sauraient agir contra legem ni preter legem mais toujurs secundum legem, c'est à-dire conformément à la loi et dans le cadre de celle-ci" (Michel Stassinopoulus, Traité des acts administratifs, pp. 18-19). 
Toda acción administrativa se nos presenta así como ejercicio de un poder atribuido previamente por la Ley y por ella delimitado y construido. Sin una atribución legal previa de potestades la Administración no puede actuar, simplemente. ${ }^{17}$

Há assim inegável submissão da função administrativa à legislativa. Só há espaço para manifestação da primeira nas hipóteses em que haja prévia autorização legal, e nos estritos limites de tal autorização. Essa subordinação pode ser entendida tanto num sentido negativo como num positivo: a função administrativa não só deve ser exercida conforme dispuser a lei, mas também somente pode ser exercida se houver autorização legal. ${ }^{18}$

É possível analisar a subordinação da função administrativa à legislativa sob um duplo aspecto.

Sob a ótica da estrutura do ordenamento jurídico, hierarquizado e em forma escalonada, tal qual proposto por Hans Kelsen, ${ }^{19}$ os atos administrativos resultam de atividade de aplicação do direito e são válidos se compatíveis, material e formalmente, com as normas que os antecedem (atos de criação do direito). ${ }^{20}$

A segunda análise possível leva em consideração o diferente papel desempenhado por órgãos administrativos e órgãos legislativos, especialmente num Estado Democrático de Direito.

Cabe à função legislativa eleger o interesse público que, num determinado momento histórico, é relevante para a comunidade. Inovando a ordem jurídica, a lei

17 Curso de derecho administrativo, p. 433.

18 "Tale subordinazione, che concreta il principio della necessaria legalità dell'attività amministrativa, va intesa anzituto in senso negativo: vale a dire nel senso che l'attività amministrativa trova un limite formalmente insuperabile nella legge, la quale può porre divieti a determinate attività, tanto per quello che concerne le finalità da raggiungere, quanto per quello che riguarda $i$ mezzi e le forme da seguirsi a tale scopo; ma va intesa, anche e soprattutto, in senso positivo: $e$ questo non soltanto nel senso che la legge può vincolare positivamente l'attività amministrativa a determinate finalità od a determinate mezzi o determinate forme, ma altresi nel senso che ... l'amministrazione, particolarmente per quanto concerne l'attività di carattere giuridico, può fare soltanto ciò che la legge consente" (Renato Alessi, Principi di diritto amministrativo, p. 16).

19 Para Kelsen, "a ordem jurídica não é um sistema de normas jurídicas ordenadas no mesmo plano, situadas umas ao lado das outras, mas é uma construção escalonada de diferentes camadas ou níveis de normas jurídicas. A sua unidade é produto da conexão de dependência que resulta do facto de a validade de uma norma, que foi produzida de acordo com outra norma, se apoiar sobre essa outra norma, cuja produção, por seu turno, é determinada por outra; e assim por diante, até abicar finalmente na norma fundamental - pressuposta. A norma fundamental - hipotética, nestes termos - é, portanto, o fundamento de validade último que constitui a unidade desta interconexão criadora" (A teoria pura do direito, p. 310).

20 Segundo Eduardo García de Enterría, "el proceso de producción jurídica es un proceso de legis executio paulatina a partir de la norma fundamental; en la medida en que la Administración se inserta necesariamente en una fase de ese proceso no puede actuar más que ejecutando normas antecedentes" (ob. cit., p. 430). 
define o que é de interesse público, tendo como limite unicamente o texto constitucional. ${ }^{21}$

Em seu papel subordinado à lei formal, aos órgãos que desempenham função administrativa não cabe a escolha do que é interesse público. Tal definição já foi feita pelo legislador. Ao aparato administrativo do Estado compete adotar as medidas de atendimento do interesse público, previamente eleito pelo Parlamento, na forma estabelecida em lei. Veja-se a lição de Fernando Sainz Moreno:

en un Estado democrático y libre sólo al legislador corresponde fijar lo que conviene al interés público. El legislador, si es representante de la voluntad del pueblo, expresa por medio de sua actuación legislativa la concepción que en cada momento prevalece del interés público. (...) No es misión de la Administración descubrir en cada momento y ante cada caso lo que conviene al interés público; su tarea, por el contrario, es concretar y aplicar la idea de interés público que la Ley expresa. ${ }^{22}$

Cite-se ainda a seguinte passagem da obra de Celso Antônio Bandeira de Mello, que bem demonstra a relação da função administrativa em face da legislativa:

Administrar é prover aos interesses públicos, assim caracterizados em lei, fazendo-o na conformidade dos meios e formas nela estabelecidas ou particularizadas segundo suas disposições. ${ }^{23}$

Em face do que foi exposto, pode-se definir função administrativa como a atividade estatal infralegal que visa ao atendimento dos interesses públicos eleitos pelo legislador, cujos atos são passíveis de controle pelo Poder Judiciário. ${ }^{24}$

21 “À questão 'que é interesse público?' poder-se-á responder de maneira singela: 'aquilo que a lei assim quis'. Interesse público, dentro de determinado ordenamento jurídico-positivo, é aquele a que a Constituição e a lei deram tratamento especial" (Lucia Valle Figueiredo, Curso de direito administrativo, p. 33).

22 Reducción de la discrecionalidad: el interés público como concepto juridico, p. 9-10. Em sentido semelhante é a lição de Georges Vedel: "Pour que la notion d'intérêt public soit juridiquement utilisable, il faut que soient déterminées les autorités qui ont compétence pour arbitrer entre les intérêts particuliers. (...) Pourtant, c'est généralement au législateur qu'il revient de définir avec la precision nécessaire la plupart des éléments composant l'intérêt public. (...) Le législateur ne se contente d'ailleurs pas en général de définir la fin d'intérêt public. Il définit aussi les règles juridiques selon lesquelles cette fin sera poursuivie: autorité compétente pour intervenir en la matière, moyens dont elle pourra user. Quant à l'Administration, elle n'est pas, en droit, compétente pour définir les fins d'intérêt public et en créer de nouvelles" (Droit administratif, p. 174).

23 Ob. cit., p. 76.

24 A menção ao controle do Poder Judiciário é necessária em face do que dispõe o inciso XXXV do art. $5^{\circ}$ da Constituição Federal. Note-se que a definição proposta é compatível com o ordenamento jurídico nacional, em decorrência dos seguintes dispositivos constitucionais: art. $5^{\circ}$, incisos II e XXXV (já mencionado); art. 37, caput; art. 84, inciso IV. Não se trata, porém, de definição de validade universal e intemporal. A definição de cada função estatal, como já foi dito, deve levar 


\subsection{A finalidade como elemento do ato administrativo}

A conceituação de ato administrativo extrapola os limites do presente estudo. Considerar-se-á, aqui, ato administrativo como o resultado do exercício da função administrativa, acima definida. É, portanto, um ato estatal infralegal pelo qual o aparato administrativo do Estado busca atender os interesses públicos eleitos pelo legislador, e, ademais, sujeito ao controle jurisdicional. À sua conceituação, no modo proposto, não importa o conteúdo do ato, mas tão-somente sua posição no ordenamento jurídico. $\mathrm{O}$ ato administrativo, portanto, pode ser tanto individual e concreto (ato administrativo stricto sensu) como geral e abstrato (regulamento). ${ }^{25}$

Em poucos temas do direito administrativo encontra-se tamanha discrepância como a que reina acerca dos elementos do ato administrativo. Em geral, são apontados cinco elementos: competência (ou sujeito), motivo, finalidade, forma e objeto. Há, porém, posições doutrinárias as mais diversas: ora divergem os autores quanto à nomenclatura, ora quanto ao número de elementos. Autores há ainda que preferem nem usar a expressão elementos, manifestando sua opção por outras, como requisitos ou pressupostos dos atos administrativos.

O tema escapa dos limites do presente trabalho e, além disso, é inútil para o objeto ora estudado. Isso porque a finalidade - e o tema em discussão é o desvio de finalidade - é considerada pela grande maioria dos autores como elemento do ato administrativo, havendo nesse tópico pequena variação. ${ }^{26}$

E o que é a finalidade do ato administrativo?

Como foi dito, o legislador define o interesse público através do exercício da função legislativa. Ademais, é o legislador que atribui competências aos órgãos administrativos do Estado, que as devem exercer nos estritos limites legais.

Ao outorgar competência à Administração Pública, o legislador tem em mira um determinado interesse público que deverá ser atendido pela atuação administrativa. Ou seja, a competência é outorgada visando a uma específica finalidade, a um resultado que deve ser alcançado pelo ato praticado. Cite-se, uma vez mais, a preciosa lição de García de Enterría:

Los poderes administrativos no son abstractos, utilizables para cualquier finalidad; son poderes funcionales, otorgados por el Ordenamiento en vista

em conta o regime jurídico que lhe é próprio, e depende, pois, da análise do ordenamento jurídico de cada Estado.

25 " $A$ ação administrativa vem a ser constituida por voliçôes secundárias, em relação às voliçōes primárias do legislador, para a realizaçāo dos fins por este prefixados. Estas voliçôes secundárias são de duas ordens: umas genéricas, como as próprias leis a executar, outras individuais e concretas" (Afonso Rodrigues Queiró, Lições de direito administrativo, p. 66).

26 Independente da questão terminológica, consideram a finalidade um elemento do ato administrativo os seguintes autores, dentre tantos: Celso Antônio Bandeira de Mello (ob. cit., p. 347-348), Oswaldo Aranha Bandeira de Mello (ob. cit., pp. 521-522), Seabra Fagundes (ob. cit., p. 38), Eduardo García de Enterría, (ob. cit., p. 544). Ver, em contrário, André Gonçalves Pereira, Erro e ilegalidade do acto administrativo, pp. 108-109. 
de un fin específico, con lo que apartarse del mismo ciega la fuente de su legitimidad. ${ }^{27}$

A finalidade é justamente o resultado visado pela lei que outorga competência à Administração Pública. É, em outras palavras, o objetivo que o ato administrativo deve alcançar, de acordo com o comando legal. Ou ainda, nas palavras de Celso Antônio Bandeira de Mello, "o bem jurídico objetivado pelo ato (...) o resultado previsto legalmente como o correspondente à tipologia do ato administrativo" ${ }^{28}$

Como é óbvio, a finalidade será sempre um interesse público: "o fim é, pois, aquêle interêsse público cuja realização a lei tem em vista ao conceder a determinada autoridade certo poder de agir", conforme a lição do mestre português Afonso Rodrigues Queiró. ${ }^{29}$ Exercendo função, não haveria justificativa para o legislador outorgar competência aos órgãos administrativos com objetivo outro que o atendimento do interesse público. Pela mesma razão, não haveria fundamento para o agir da Administração Pública que não tivesse em mira o mesmo objetivo.

Cada ato administrativo tem uma finalidade própria, que deve ser alcançada através da sua edição. São sempre interesses públicos, vale repetir, mas que variam conforme o caso. Conforme lição de García de Enterría, o interesse público genérico "se matiza significativamente en cada uno de los setores de actividad o institucionales como un fin específico (p. ej., en la potestad de policía, la seguridad pública, en las potestades sanitarias, la salubridad etc)". ${ }^{30}$

Assim, p. ex., a desapropriação de imóvel rural prevista no art. 184 da Constituição Federal, de competência privativa da União Federal (Lei complementar $\mathbf{n}^{\circ}$ $76 / 93$, art. $2^{\circ}$ ) tem por finalidade a realização de reforma agrária. Ou seja, a competência outorgada à União pelo referido diploma legal somente poderá ser exercida, licitamente, se tiver em mira tal objetivo, sob pena de invalidade, como adiante será analisado. Visando à reforma agrária não pode a União Federal lançar mão da competência outorgada pelo Decreto-lei $n^{\circ} 3.365 / 41$, que trata da desapropriação por utilidade pública, já que a finalidade legal, em tal caso, é distinta daquela. ${ }^{31}$

27 Ob. cit., p. 458. Para ficar na rica doutrina do direito administrativo espanhol, cite-se a brilhante passagem de Carmen Chinchilla Marin: "en toda actuación administrativa hay, por decirlo de una manera muy simple, un por quê y un para quê. La Administración actúa porque una norma la ha apoderado en ese sentido para que cumpla una finalidad de interés público concreta" (La desviación de poder, p. 69).

28 Ob. cit., p. 347.

29 A teoria do desvio de poder em direito administrativo, RDA vol. VII, pp. 69-70.

30 Ob. cit., p. 544. No mesmo sentido a lição de Jean Rivero: "De modo geral, [a Administração Pública] só deve exercer as suas competências com vista à satisfação do interesse público. em virtude de um princípio geral do direito. De modo mais particular, os textos assinalaram a certas competências um fim preciso: os poderes de polícia têm por finalidade assegurar a manutenção da ordem, o processo de alinhamento tem por finalidade fixar os limites da via pública etc" (Direito administrativo, pp. 289-290).

31 De acordo com o art. $5^{\circ}$ do Decreto-lei no $3.365 / 41$, "Consideram-se casos de utilidade pública: a) a segurança nacional; b) a defesa do Estado; c) o socorro público em caso de calamidade; d) a 
É verdade que nem sempre a lei que confere competência à Administração Pública é expressa ao determinar o interesse público cujo atendimento deve ser o objetivo do ato administrativo. Se pode a lei ser bastante precisa ao discriminar o interesse que está vinculado à competência administrativa, especificando a sua natureza (sanitário, econômico, estético etc), pode também, por outro lado, simplesmente fazer referência ao interesse público, genericamente. É possível, ainda, que a lei refira-se ao interesse público de modo implícito. ${ }^{32}$ Sempre haverá, entretanto, um interesse público como alvo do agir da Administração Pública. ${ }^{33}$

Esclarecido o conceito de finalidade, deve-se examinar outra questão tormentosa, a saber: há espaço para a discricionariedade na definição da finalidade do ato administrativo? $?^{34}$

De início, importante mencionar que não existe propriamente ato administrativo discricionário. Isso porque a margem de liberdade de que dispõe a Administração Pública jamais é absoluta, ilimitada. Bem pelo contrário, há sempre vinculação na competência administrativa, menor ou maior. O legislador pode conferir certa liberdade aos órgãos administrativos, mas tal liberdade coexiste com a vinculação, que em hipótese alguma pode desaparecer. É dizer, a discricionariedade não se refere nunca ao ato administrativo em sua totalidade, mas apenas a alguns aspectos do ato. Transcreva-se, nesse sentido, a lição sempre precisa de Victor Nunes Leal:

“Conquanto não haja atos integralmente discricionários, entretanto para a prática de certos atos administrativos a Constituição e as leis costumam

salubridade pública; e) a criação e melhoramento de centros de população, seu abastecimento regular de meios de subsistência; f) o aproveitamento industrial das minas e das jazidas minerais, das águas e da energia hidráulica; g) a assistência pública, as obras de higiene e decoração, casas de saúde, clínicas, estações de clima e fontes medicinais; h) a exploração e a conservação dos serviços públicos; i) a abertura, conservação e melhoramento de vias ou logradouros públicos; a execução de planos de urbanização; o parcelamento do solo, com ou sem edificação, para sua melhor utilização econômica, higiênica ou estética; a construção ou ampliação de distritos industriais; $j$ ) o funcionamento dos meios de transporte coletivo; $k$ ) a preservação e conservação dos monumentos históricos e artísticos, isolados ou integrados em conjuntos urbanos ou rurais, bem como as medidas necessárias a manter-lhes e realçar-lhes os aspectos mais valiosos ou característicos $\mathrm{e}$, ainda, a proteção de paisagens e locais particularmente dotados pela natureza; l) a preservação e a conservação adequada de arquivos, documentos e outros bens móveis de valor histórico ou artístico; m) a construção de edifícios públicos, monumentos comemorativos e cemitérios; $n$ ) a criação de estádios, aeródromos ou campos de pouso para aeronaves; o) a reedição ou divulgação de obra ou invento de natureza científica, artística ou literária; p) os demais casos previstos por leis especiais".

32 Renato Alessi, ob. cit., pp. 236-237.

33 Vale ser transcrita, aqui, a lição de Carmen Chinchilla Marin: "la búsqueda de ese fin que constituye la causa de cada acto y que, expresa o implícitamente, fija la ley, no siempre resulta fácil, ya que el interés general al que genéricamente sirve la Administración (art. 103.1 CE) tiene una manifestación específica en cada actuación administrativa, y es a esa finalidad a la que habrá que referir la desviación" (ob. cit., p. 126).

34 Entende-se por discricionariedade a margem de liberdade que o legislador atribui à Administração Pública para que esta defina, através de juízo subjetivo próprio e dentro dos limites legais, a melhor maneira de atender o interesse público eleito pelo legislador. 
reservar à administração pública uma opção de conveniência e oportunidade. A opção de conveniência e oportunidade é que constitui o conteúdo discricionário do ato, mas, salvo no tocante a êsse ponto, o ato administrativo, em tudo o mais, se deve considerar vinculado." 35

A doutrina costuma afirmar que a finalidade é elemento vinculado do ato administrativo. ${ }^{36} \mathrm{~A}$ afirmação parece óbvia. Afinal, se a finalidade é o interesse público que a lei determina que a Administração Pública persiga ao exercer a competência que lhe foi outorgada, salta aos olhos que não há, aqui, liberdade de escolha alguma à disposição dos órgãos administrativos. Não é admissível que o órgão administrativo afaste-se do interesse público que está no fundamento da sua própria competência. Muito embora sejam verdadeiras tais afirmações, a análise não é tão simples como pode parecer num primeiro momento.

É sabido que o legislador, ao editar seus atos normativos no exercício da função legislativa, pode utilizar conceitos precisos e imprecisos. De fato, pode o legislador tanto dispor que "aos 21 anos completos acaba a menoridade" (Código Civil, art. $9^{\circ}$ ), como que constitui crime "raptar mulher honesta para fim libidinoso" (Código Penal, art. 219). No primeiro caso o conceito é preciso, não havendo espaço para juízo valorativo algum: em determinado dia o indivíduo completa 21 anos, e como consequiência cessa a sua menoridade. Já no segundo exemplo o conceito utilizado pelo legislador é impreciso: definir o que seja mulher honesta depende da análise de uma série de fatores, muitos dos quais altamente subjetivos.

35 Problemas de direito público, p. 281. Deve ser transcrita ainda a lição de Léon Duguit a respeito: : "A mon avis, on doit énergiquement affirmer que dans le droit français moderne, non seulement il n'y a pas d'acte arbitraire, mais qu'il n'y a pas d'acte discrétionnaire ou de pure administration. Quelque large que puisse être parfois le pouvoir d'appréciation de l'agent administratif, celui-ci ne peut jamais être déterminé par un but étranger à un service public, ni même par un but de service public sans doute, mais étranger aux services publics qu'avait certainement en vue la loi en lui donnant compétence" (Traité de droit constitutionnel, p. 303).

36 É a opinião de García de Enterría: "En concreto puede decirse que son cuatro por lo menos los elementos reglados por la Ley en toda potestad discrecional y que no pueden dejar de serlo: la existencia misma de la potestad, su extensión (que nunca podrá ser absoluta, como ya sabemos), la competencia para actuarla, ..., y por último, el fin, porque todo poder es conferido por la Ley como instrumento para la obtención de una finalidad específica, la cual estará normalmente implícita y se referirá a un sector concreto de las necesidades generales, pero que en cualquier caso tendrá que ser necesariamente una finalidad pública" (ob. cit., p. 446). Semelhante é a lição de Hely Lopes Meirelles: "a finalidade do ato administrativo é aquela que a lei indica explicita ou implicitamente. Não cabe ao administrador escolher outra, ou substituir a indicada na norma administrativa, ainda que ambas colimem fins públicos. Neste particular, nada resta para escolha do administrador, que fica vinculado integralmente à vontade legislativa" (ob. cit., p. 135). No mesmo sentido ensina Caio Tácito: "A finalidade é um elemento de vinculação permanente da conduta administrativa: se pode haver discricionariedade no tocante à escolha dos motivos ou à determinação do objeto, em nenhuma hipótese ela ocorrerá em relação ao fim" (Direito administrativo, p. 101). 
Importa ainda notar: no primeiro caso não haverá margem de dúvida alguma quanto à verificação do conceito; será apenas uma questão de definir datas, com base nas quais será possível afirmar, com certeza, que o indivíduo completou ou não 21 anos. Na segunda hipótese, pelo contrário, sempre será possível questionar a adequação do conceito ao caso concreto, sendo certo que em alguns casos a adequação ou inadequação será induvidosa, enquanto noutros haverá margem de dúvida quanto à subsunção do caso concreto ao conceito legal.

Tal indefinição é típica dos conceitos vagos, imprecisos, indeterminados. É que, como ensina Karl Engisch, na esteira do pensamento de Philipp Heck, os conceitos jurídicos indeterminados possuem um núcleo conceitual e um halo conceitual. No primeiro encontra-se uma zona de certeza positiva, e, por exclusão, outra negativa; já no segundo tem-se uma zona de incerteza. ${ }^{37}$

É justamente a zona de incerteza existente em todo conceito jurídico indeterminado que leva à conclusão de que há discricionariedade nos casos em que o legislador outorga competência utilizando-se de tais conceitos. ${ }^{38}$

É que na zona de incerteza não se pode determinar de modo categórico se a situação de fato é ou não subsumível ao conceito legal indeterminado. Pode ser ou pode não ser, conforme juízo subjetivo de quem analisa a norma. Seja qual for a opção, não se pode dizer, objetivamente, que seja errada. Em outras palavras: na zona de incerteza a determinação da adequação do conceito legal ao caso concreto decorre de análise subjetiva do aplicador da norma.

Ora, se o legislador utiliza conceitos jurídicos indeterminados para delimitar a competência administrativa, atribui ao agente administrativo o poder de definir se o fato concreto é ou não subsumível ao conceito legal. Faz parte da competência do agente administrativo, em tais hipóteses, definir se o caso concreto é ou não adequado ao conceito indeterminado contido na lei.

Esclareça-se, porém, que a liberdade do agente administrativo no seio dos conceitos jurídicos indeterminados não é, em hipótese alguma, absoluta. Como se disse, há uma zona de certeza em tais conceitos, na qual não há liberdade à disposição da Administração Pública. A liberdade surge apenas na zona de incerteza, em que não se pode afirmar de modo objetivo que se está ou não diante de um fato subsumível ao conceito legal. Apenas aqui há discricionariedade. Ou, nas palavras claras de Celso Antônio Bandeira de Mello: “a discricionariedade fica acantonada nas regiões em que a dúvida sobre a extensão do conceito ou sobre o alcance da vontade legal é ineliminável". 39

37 "Que numa noite sem luar, pelas vinte e quatro horas, nos espaços não iluminados, domina a escuridão à nossa latitude, é uma coisa clara; dúvidas fazem já surgir as horas do crepúsculo" (Introdução ao pensamento jurídico, pp. 173-174).

38 Daí a lição de Afonso Rodrigues Queiró: " a discricionariedade surge, assim, circunscrita aos conceitos de valor utilizados na norma jurídica, aos conceitos práticos (nāo teoréticos)" (A teoria do desvio de poder em direito administrativo, RDA vol. VI, pp. 60-61). Em sentido contrário, ver Eduardo García de Enterría, ob. cit., pp. 448-455.

39 Ob. cit., p. 763. Em outra obra, ensina o mesmo mestre: "o agente público estará sempre 'vinculado' ao campo de certeza positiva e ao campo de certeza negativa abrigado nas palavras 
Fixada a idéia de que há discricionariedade na competência delimitada através de conceitos jurídicos indeterminados, a coerência impõe o reconhecimento de que pode haver discricionariedade na delimitação da finalidade do ato administrativo. Basta, com efeito, que a finalidade seja veiculada através de conceito vago, impreciso. Isso não significa, obviamente, que será lícito ao agente administrativo perseguir finalidade diversa do interesse público tal qual eleito pelo legislador. Significa tão-somente que o agente é competente para delimitar qual é o interesse público que corresponde à finalidade do ato administrativo. ${ }^{40}$

Tome-se como exemplo lei que outorgue competência à Administração Pública para pôr fim a reuniões que causem danos à ordem pública. A finalidade, aqui, é manter a ordem pública. A definição de ordem pública, porém, depende de juízo subjetivo do aplicador da norma. Haverá, é certo, reuniões que obviamente não causarão transtorno algum à ordem pública (zona de certeza negativa), e outras que induvidosamente causarão (zona de certeza positiva). Em tais casos não há que se falar em discricionariedade. Havendo espaço para dúvida, porém, estar-se-á diante de competência discricionária, no tocante a esse ponto específico do ato administrativo.

\section{O vício do desvio de poder}

\subsection{Recapitulação; conceito de desvio de poder}

Conforme foi afirmado no capítulo anterior, a função administrativa é subordinada à legislativa. Com efeito, só é possível à Administração Pública agir se houver lei formal que lhe outorgue competência, e mais, nos precisos limites da lei autorizadora.

A lei formal, também foi dito, outorga competência aos órgãos administrativos do Estado tendo em mira um específico interesse público, que deve ser o alvo da atuação administrativa. Tem-se aqui a finalidade do ato administrativo, que é o objetivo (interesse público) que deve ser alcançado através do exercício da competência administrativa, de acordo com o comando legal.

Pois bem. Dito isso, é possível - e até mesmo intuitivo - definir o vício ora estudado: desvio de poder (ou de finalidade) é o exercício de uma competência administrativa tendo em mira finalidade diversa da que lhe corresponde segundo $o$ comando legal. ${ }^{41}$

em questão, pois nāo está autorizado a fazer delas uma intelecção desarrazoada, arbitrária, distinta do senso comum, liberta do sentido corrente que necessariamente lhes terá de ser reconhecido em dado tempo e lugar" ( "Relatividade" da competência discricionária, p. 14).

40 Nesse sentido, Celso Antônio Bandeira de Mello, ob. cit., p. 758-760; Afonso Rodrigues Queiró, A teoria do desvio de poder em direito administrativo, RDA vol. VI, p. 78; Renato Alessi, ob. cit., p. 236.

41 "Il y a détoumement de pouvoir lorsqu'une autorité administrative accomplit un acte de sa compétence mais en vue d'un but autre que celui pour lequel l'acte pouvait légalement être 
O ato praticado com desvio de finalidade é inválido, não podendo sequer ser objeto de convalidação. ${ }^{42}$

\subsection{Origem histórica}

\subsubsection{França e Itália}

O desvio de poder surge da criatividade jurídica do Conselho de Estado francês, que buscava um instrumento para controlar a discricionariedade administrativa. Ampliando a abrangência do recours pour excès de pouvoir, chegou o Conselho de Estado ao détournement de pouvoir, figura que atualmente está difundida na doutrina não só da França mas de diversos países, inclusive o Brasil.

$\mathrm{O}$ recurso de excès de pouvoir francês visa à anulação dos atos administrativos praticados em ofensa à lei. ${ }^{43}$ Num primeiro momento, a anulação decorria tão-somente da incompetência do agente, para em seguida abranger também os casos de vício de forma. Tratava-se, então, de um recurso contra vícios externos de ilegalidade dos atos administrativos.

$\mathrm{Na}$ sequiência, o Conselho de Estado passou a aceitar o recurso para invalidar atos que padeciam de vícios internos de ilegalidade, que atingiam o motivo, o conteúdo e a finalidade do ato administrativo. ${ }^{44}$

Ao permitir que o recurso de excesso de poder fosse utilizado como instrumento para invalidar os atos administrativos viciados em sua finalidade, deu origem o Conselho de Estado francês à teoria do desvio de poder. Foram os célebres arrêts Lesbats, de 25 de fevereiro de 1864 e 17 de junho de 1865 , que marcaram a adoção da nova orientação da jurisprudência francesa.

accompli" (André de Laubadère, Traité de droit administratif, p. 538); "la desviación de poder es un vicio del acto administrativo que consiste precisamente en el ejercicio de potestades administrativas para fines distintos de los señalados por el ordenamiento juridico" (Carmen Chinchilla Marin, ob. cit., p. 51); "entende-se por desvio de poder a utilização de uma competência em desacordo com a finalidade que lhe preside a instituição" (Celso Antônio Bandeira de Mello, Discricionariedade e controle jurisdicional, p. 56).

42 A possibilidade de convalidação é o critério mais relevante de distinção entre categorias de atos administrativos inválidos, o que levou Antônio Carlos Cintra do Amaral a rejeitar a nomenclatura tradicional - atos nulos e anuláveis - e adotar outra: atos convalidáveis e não-convalidáveis (Extinção dos atos administrativos, p. 66). Sobre a impossibilidade de convalidação dos atos administrativos maculados pelo desvio de poder, ver Weida Zancaner, Da convalidação e da invalidação dos atos administrativos, p. 76.

43 "Le recours pour excès de pouvoir fait partie du contentieux de la legalité. Cette proposition qui achève de préciser la nature du recours signifie que le juge de l'excès de pouvoir limite son contrôle à une confrontation entre l'acte critiqué et la règle de droit. Excès de pouvoir est synonyme d'illegalitê" (André de Laubadère, ob. cit., p. 502).

44 Atualmente são quatro os "cas d'ouverture du recours pour excès de pouvoir": incompetência, vício de forma, violação da lei (vício de motivos e vício de conteúdo) e desvio de poder. Ver, a propósito, André de Laubadère, ob. cit., pp. 533-534; Jean Rivero, ob. cit., pp. 283-284; René Chapus, Droit administratif général, p. 998. 
As mencionadas decisões anularam atos administrativos praticados pelo prefeito de Fontainebleau que, no uso de atribuição que lhe era conferida para disciplinar o transporte de veículos nas cercanias da estação ferroviária municipal, acabou utilizando-se da competência para garantir o monopólio do transporte a uma determinada empresa, indeferindo requerimentos de autorização formulados por outros interessados em prestar o serviço. Não sendo essa a finalidade legal, entendeu-se que os atos padeciam do vício de détournement de pouvoir, razão pela qual foram os mesmos anulados. $^{45}$

Após décadas de utilização da figura do desvio de poder, que se tornou um dos mais eficazes instrumentos de controle da atividade administrativa, há quem aponte, na doutrina francesa, certa decadência do instituto. ${ }^{46} \mathrm{~A}$ opinião, todavia, não é pacífica. Ocorre que a jurisprudência do Conselho de Estado francês, em sua evolução, acabou por admitir meios de controle da legalidade dos atos administrativos menos subjetivos do que o desvio de poder, e, portanto, de apuração mais fácil. É o caso, principalmente, do controle dos motivos do ato administrativo, que ocupou um espaço que antes era reservado ao détoumement de pouvoir. Parece ser exagerado, portanto, falar em decadência do instituto na jurisprudência francesa. Há, isso sim, a adoção de outras técnicas de controle, ao lado da técnica do desvio de poder, que ainda mantêm sua importância. ${ }^{47}$

Na Itália o excesso de poder surge, ao menos no âmbito do direito administrativo, com a Lei de 2 de junho de 1889 (art. 24), que disciplinava as funções do Consiglio di Stato, atribuindo-lhe competência para julgar os recursos administrativos nos casos de incompetência, excesso de poder e violação à lei. ${ }^{48}$

45 Já em 19 de maio de 1858 (arrêt Vernes) o Conselho de Estado francês utilizara a noção de desvio de poder, muito embora sem utilizar a expressão que depois ficou consagrada, ao anular ato administrativo de prefeito municipal que proibia aos banhistas que trocassem de roupa em locais diversos dos estabelecimentos municipais criados com tal propósito. Entendeu o Conselho de Estado que tal proibição visava a aumentar a arrecadação municipal, já que pela utilização dos estabelecimentos municipais era cobrada uma taxa (conforme Carmen Chinchilla Marin, ob. cit., pp. 30-31). 46 Entre outros, Marcel Waline, Droit administratif, pp. 424-425; Jean Rivero, ob. cit., p. 292.

47 "Il est cependant certain que les arrêts annulant pour détournement de pouvoir sont devenus beaucoup plus rares qu'autrefois. Mais c'est pour une raison assez différente, à savoir, l'apparition (postérieur au détoumement de pouvoir) d'autres moyens d'annulation qui permettent d'aboutir à l'annulation dans des espéces où on eût autrefois recherché le détournement de pouvoir et qui, donnant lieu à des appréciations moins subjective, offrent un terain plus favorable et sont, de ce fait, préférées par les plaideurs et par le juge. Plutôt que de déclin du détournement de pouvoir il vaut donc mieux parler d'une raréfaction expliquée par un transfert de moyens d'annulation" (André de Laubadère, ob. cit., pp. 542-543). No mesmo sentido, Eduardo García de Enterria, ob. cit., pp. $461-462$.

48 O referido diploma legal foi substituído pelo Regio Decreto $\mathrm{n}^{\circ} 1.054$, de 26 de junho de 1924 , que dispõe em seu art. 26, de modo semelhante ao que dispunha o art. 24 da Lei de 1889, o seguinte: "Spetta al Consiglio di Stato in sede giurisdizionale di decidere sui ricorsi per incompetenza, per eccesso di potere o per violazione di legge, contro atti e provvedimenti di un'autorità amministrativa o di un corpo amministrativo deliberante,...". 
À época, a jurisprudência francesa já criara o conceito de détoumement de pouvoir, incluindo tal figura dentre os casos que permitiam o controle de legalidade dos atos administrativos através do recurso de excès de pouvoir. A jurisprudência italiana soube aproveitar, desde o primeiro instante, a inovação criada pelo Conselho de Estado francês. Assim, já a partir de 1889, com a edição do referido diploma legal, é exercido na Itália o controle do eccesso di potere, incluindo aí a figura específica do desvio de finalidade (sviamento di potere) ${ }^{49}$

$\mathrm{O}$ excesso de poder italiano não se restringe à figura do desvio de finalidade. ${ }^{50}$ Pelo contrário, abrange uma grande quantidade de vícios dos atos administrativos, em especial os que decorrem do exercício de competência discricionária. ${ }^{51}$ Podem ser destacados os seguintes: inexistência dos pressupostos de fato invocados, erro de fato, ilogicidade manifesta, injustiça manifesta, entre outros. ${ }^{52}$

Da jurisprudência e doutrina francesa e italiana o desvio de finalidade passou a ser adotado em diversos sistemas jurídicos, como o da Espanha, de Portugal, da Bélgica, dos Estados Unidos, do México e do Brasil, ao qual serão dedicados os próximos itens do presente estudo. ${ }^{53}$

\subsubsection{A origem do desvio de finalidade no Brasil}

No Brasil a adoção da teoria do desvio de poder foi bem mais tardia do que no continente europeu, infelizmente. Ainda que já no final do século XIX a Lei $n^{\circ} 221$, de 20 de novembro de 1894 fizesse expressa referência ao excesso de poder como causa de invalidade de "medida administrativa tomada em virtude de uma faculdade ou poder discricionário", não houve, como ocorrera na Itália apenas cinco anos antes, a percepção da oportunidade que se abria ao controle dos atos administrativos, através da utilização da teoria já então consagrada no direito administrativo francês.

49 Guido Zanobini, ao fazer referência ao détournement de pouvoir francês, assim se manifesta: "Tale era il significato assunto dall'eccesso di potere nella giurisprudenza francese, quando l'espressione fu introdotta nella legislazione italiana con riferimento agli atti amministrativi; $e$ in questo senso essa fu intesa ed applicata immediatamente dal nostro Consiglio di Stato" (Corso di diritto amministrativo, p. 202).

50 Não são figuras iguais o eccesso di potere italiano e o excès de pouvoir francês. O eccesso di potere é uma das formas de ilegalidade dos atos administrativos, ao lado da incompetência e da violação à lei. $\mathrm{O}$ excès de pouvoir francês é o recurso utilizado para invalidar atos administrativos viciados, e abrange todas as formas de ilegalidade: incompetência, vício de forma, violação à lei, desvio de poder. Podem ser considerados sinônimos, entretanto, o sviamento di potere e o détournement de pouvoir.

51 De acordo com Renato Alessi, o excesso de poder abrange " $i$ vizi inerenti alla violazione da parte dell "Amministrazione dei limiti posti alla sua potestà discrezionale" (ob. cit., p. 417).

52 Guido Zanobini, ob. cit., p. 202. Ver ainda Umberto Fragola, Gli atti amministrativi, p. 161: "lo sviamento dal fine pubblico, la contraddizione, la disparità di trattamento, la motivazione illogica, la iniquità e la ingiustiza manifesta sono le forme più frequente di eccesso di potere".

53 Para uma visão do desvio de finalidade no direito comparado, ver Caio Tácito, ob. cit., pp. 90-98. 
A verdade é que o silêncio sobre o desvio de poder marcou as primeiras décadas do século XX. Tal situação pode ser explicada pelo receio de que o Poder Judiciário invadisse a esfera de atuação da Administração Pública, ao examinar a compatibilidade do ato administrativo com a finalidade legal. Dúvida não há que o fato de na França e na Itália o controle da finalidade do ato administrativo ser exercido, principalmente, por órgão da jurisdição contenciosa-administrativa facilitou bastante a aceitação da teoria nos referidos países. Pelo contrário, a inexistência de um órgão de tal natureza no Brasil dificultou a importação da idéia desenvolvida pelo Conselho de Estado francês. Não faltou, aliás, quem afirmasse que a teoria do desvio de poder era compatível apenas com os sistemas que contemplassem um órgão de jurisdição administrativa, e, portanto, seria inaceitável no Brasil a sua adoção. ${ }^{54}$

Coube ao jurista potiguar Seabra Fagundes, figura que engrandeceu as letras jurídicas brasileiras do século $\mathrm{XX}$, o tratamento mais aprofundado do desvio de finalidade como vício do ato administrativo. Já em 1941, na primeira edição de sua principal obra - nunca suficientemente elogiada -, $O$ controle dos atos administrativos pelo Poder Judiciário, arrolava Seabra Fagundes o desvio de finalidade entre os motivos de invalidação dos atos administrativos, reconhecendo que:

A atividade administrativa sendo condicionada pela lei à obtenção de determinados resultados, não póde a Administração Pública deles se desviar, demandando resultados diversos dos visados pelo legislador. Os atos administrativos devem procurar atingir as conseqüências que a lei teve em vista quando autorizou a sua pratica, sob pena de nulidade. Tratando, por exemplo, de desapropriação, a Carta Constitucional a permite para atender á necessidade ou utilidade pública. Decretada a expropriação de um imóvel no interêsse direto de pessôa privada, o ato será invalido por falta de finalidade legal. Terá havido ai desvio de finalidade, ou seja, o que os francêses chamam de detournement de pouvoir. ${ }^{55}$

54 É o caso, p. ex., de Themístocles Cavalcanti, que ensinava: "Em nosso regime, sòmente a própria autoridade administrativa, dentro de sua competência legal, pode corrigir os vícios dos atos administrativos que decorrem do motivo determinante do ato, da sua justiça, oportunidade. Esta esfera é impenetrável à autoridade judiciária, adstrita à apreciação da legalidade do ato. Assim, não é tolerável entre nós a doutrina francesa, salvo para os efeitos criminais, aplicada quando o funcionário age dolosamente, usando de meios não admitidos pela lei, deformando, quanto aos seus fins e modo de proceder, uma atribuição legal" (Tratado de direito administrativo, vol. II, pp. 294-25). Em outra passagem de sua obra, o insigne jurista afirmava, ao tratar especificamente do desvio de poder: " sòmente nos países onde existe o contencioso administrativo ou uma jurisdiçâo administrativa própria e autònoma, seria possível penetrar na apreciação do ato discricionário, ou, em outras palavras, para usar uma terminologia muito de agrado dos autores alemães, abuso do poder discricionário" (Tratado de direito administrativo, vol. VI, pp. 160-161).

$55 O$ côntrole dos atos administrativos pelo Poder Judiciário, 1941, p. 57. 
Foi o mesmo Seabra Fagundes o relator do julgado que inovou a jurisprudência brasileira sobre o tema, ao invalidar ato administrativo praticado no exercício de competência discricionária em violação à finalidade legal. $\mathrm{O}$ aresto, do Tribunal de Justiça do Rio Grande do Norte, é considerado o leading-case no tocante à teoria do desvio de poder na jurisprudência pátria. ${ }^{56}$

Coincidentemente, o caso submetido à apreciação do Tribunal de Justiça potiguar em muito se assemelhava ao que fora apreciado pelo Conselho de Estado francês em 1864, dando origem ao arrêt Lesbats. Tratava-se, com efeito, de mandado de segurança impetrado contra decisão administrativa que indeferira requerimento de empresa de ônibus que desejava prestar o serviço de transporte num determinado horário, em prejuízo de outra empresa, beneficiada pelo ato administrativo impugnado. Vale ser transcrito o seguinte trecho do voto proferido pelo eminente Seabra Fagundes:

$o$ ato administrativo que fixou horários para as viagens de ida e vinda do terceiro ônibus do impetrante (10he $22 \mathrm{~h}$ ), se depreende do exame conjunto das peças do processo, apesar de praticado no exercício de legítima competência ( $C$. de Trânsito, arts. 56, $\S 2^{\circ}$ e 57, c) e de ter objetivo lícito (coordenação dos transportes coletivos entre São José de Mipibu e esta Capital), peca por desvio de finalidade, pois longe de visar, como seria de supor, o exclusivo interêsse público a um bom serviço de comunicações, o que teve em mira foi cercear a atividade do impetrante favorecendo o seu concorrente. $^{57}$

Do ponto de vista legislativo, é curioso notar que o ordenamento jurídico pátrio sempre foi mais rico do que o francês, no que diz respeito ao vício de finalidade. Além da já citada Lei $n^{\circ} 221 / 1894$, deve-se fazer menção à Lei $n^{\circ} 1.522$, de 26 de dezembro de 1951, que em seu art. 28 alude ao desvio de poder, não para eivar de nulidade o ato administrativo, mas sim para sujeitar o agente que praticou o ato à destituição do cargo, sem prejuízo das sanções penais correspondentes.

Há que se fazer referência, ainda, à Lei no 4.717 , de 29 de junho de 1965, que disciplina a ação popular. Tal diploma legal, ao arrolar as hipóteses de nulidade dos atos administrativos, faz expressa menção ao desvio de finalidade (art. $2^{\circ}$, alínea $e$ ), definindo-o da seguinte maneira: “ $o$ desvio de finalidade se verifica quando o agente pratica o ato visando a fim diverso daquele previsto, explícita ou implicitamente, na regra de competência" (art. $2^{\circ}$, parágrafo único, $e$ ).

Há, portanto, no Brasil, embasamento jurisprudencial e legislativo à aplicação da teoria do desvio de poder, sendo de lamentar que sejam raros os atos administrativos invalidados por força de tal vício, não obstante seja prática corrente na vida

56 Trata-se do acórdão proferido nos autos de apelaçāo cível $n^{\circ} 1.422$, em 28 de julho de 1948 , que se encontra publicado na Revista de Direito Administrativo, vol. 14, p. 52.

57 RDA 14/69. 
administrativa brasileira a inobservância da finalidade legal no exercício das competências administrativas. ${ }^{58}$

\subsection{Configuração do desvio de poder}

\subsubsection{Considerações preliminares}

O vício de desvio de poder atinge a finalidade do ato administrativo, como visto. $O$ agente administrativo utiliza a competência que a lei lhe conferiu para atingir um fim diverso daquele que era visado pela norma. Ao agir em desrespeito à finalidade legal, a Administração Pública descumpre seu papel no ordenamento jurídico estatal, ultrapassando os limites de atuação da própria função administrativa. Nesse sentido pode-se dizer, com Maurice Hauriou, que o controle do desvio de poder marca " $l a$ subordination du pouvoir à la fonction". 59

Note-se bem: no desvio de poder o agente é competente para praticar o ato administrativo, ou seja, existe lei formal que lhe outorgou poderes para, sob determinadas circunstâncias, agir para atingir fins específicos (sempre de interesse público). $\mathrm{O}$ vício decorre justamente da utilização da competência para o atendimento de fim diverso do estabelecido na lei.

Difere, pois, o desvio de poder da incompetência. Num caso há competência, mal utilizada; noutro, carece o agente administrativo da atribuição legal para agir. A propósito, merecem transcrição as palavras precisas de Francesco Carnelutti: "l'eccesso è qualità o attitudine del potere che esiste; l'incompetenza è espressione del potere che non esiste". ${ }^{60}$

58 São de Celso Antônio Bandeira de Mello as seguintes palavras, que assentam como luvas à situação atualmente vivida em nosso país: "os casos de desvio de poder no País são incontáveis e parecem assentar-se na concep̧̧ão ingênua, até mesmo primitiva, de que as autoridades, sobretudo as investidas em cargos políticos, são como que 'donos' dos poderes públicos enquanto titularizam ditos cargos. Assim, são corriqueiras e feitas de público, ameaças de utilização da própria competência para 'retaliar' adversários políticos ou opositores que, no uso regular de competências públicas em outras esferas (como as estaduais ou municipais) ou como cidadãos resistem às orientaçôes politicas do Governo Federal as quais, muitas vezes, padecem de ilegitimidade gritante ou escandalizam pela tolice, sobretudo nos dias que correm" (Discricionariedade e controle jurisdicional, p. 68).

59 Précis de droit administratif et de droit public, p. 455.

60 Eccesso di potere, p. 33. No mesmo sentido a lição de Oswaldo Aranha Bandeira de Mello: "o desvio de poder se restringe aos casos de exercício por órgão da Administração da sua competência em desrespeito ao fim a que essa competência está sujeita, que o direito objetivo lhe demarcara. Destarte, transborda do poder que lhe fora confiado. É um controle sui generis de vício de competência, diferente dos praticados pelos órgãos administrativos incompetentes. Nestes, o agente não tem os poderes para praticar o ato, porque the falta atribuição. Lá, ele tem atribuição, $e$, portanto, poderes para praticar o ato, mas o efetiva tendo em vista fim diferente do cogitado pela ordem jurídica ao lhe confiar essa atribuição, e, conseqüentemente, o poder de atuar (ob. cit., pp. 484-485). Ver, ainda, Celso Antônio Bandeira de Mello, Discricionariedade e controle jurisdicional, pp. 57-58. 
É bem verdade que o desvio de poder pode ser reconduzido à incompetência, desde que se tenha uma concepção ampla de competência. Afinal, o agente recebe da lei formal poderes para utilizar sob determinadas circunstâncias (motivos), com o objetivo de alcançar um fim específico (finalidade), através de ato administrativo dotado de certo conteúdo e revestido de uma peculiar forma. É dizer, o agente é competente desde que respeite as diversas facetas da norma jurídica que lhe atribuiu o exercício da função administrativa.

Nesse sentido amplo, percebe-se que o agente somente tem competência para agir tendo em mira o fim previsto na lei que lhe outorgou o poder de editar o ato administrativo. Se age com outra finalidade, atuou fora da regra de competência. $\mathrm{Na}$ pena de ouro do jurista lusitano Afonso Rodrigues Queiró: "uma autoridade que prossegue fins ou interêsses que não são os que a lei lhe comete, é claro que age num domínio em que é perfeitamente incompetente". ${ }^{61}$

Ainda nesse intróito do estudo da configuração do desvio de poder, deve-se dizer que não se trata de um vício exclusivo dos atos administrativos editados no exercício de competência discricionária. É verdade que sua criação, através da jurisprudência do Conselho de Estado francês, teve por objetivo justamente limitar o poder discricionário da Administração Pública. Mas não se deve descartar que atos vinculados possam ser viciados pelo desvio de finalidade.

Veja-se que tanto no caso de competência discricionária como no de competência vinculada está a Administração Pública obrigada a observar a finalidade legal. ${ }^{62}$ Não há aqui qualquer distinção entre uma categoria de atos e outra. Por essa razão não há motivo para a exclusão de atos vinculados da seara do vício de desvio de finalidade, muito embora seja raro encontrar um caso de tal situação. ${ }^{63}$

Cite-se o exemplo invocado por Celso Antônio Bandeira de Mello, que bem ilustra a possibilidade de desvio de poder na prática de ato administrativo vinculado. Imagine-se norma jurídica que imponha às autoridades administrativas o dever de dispersar bandos de ciganos, e que ainda esclareça que se considera bando o agrupamento de mais de 15 ciganos. Confrontado o agente administrativo com um grupo de 15 ciganos, formado por um casal, seus 12 filhos e a mãe do chefe de família, ser-lhe-ia lícito dispersar o grupo invocando a hipotética norma jurídica? Parece claro que não, pois a finalidade de tal norma não seria colocar fim a grupos familiares, mas sim a agrupamentos que viessem a causar danos à ordem pública. Nas palavras do mestre paulista:

61 A teoria do desvio de poder em direito administrativo, RDA vol. VII, p. 58. Em sentido semelhante, Celso Antônio Bandeira de Mello, Discricionariedade e controle jurisdicional, pp. 61-62: " nāo há competência - em última instância - senão quando concorrem todos os requisitos legais que lhe delineam a concreta compostura".

62 "Todo ato administrativo tem por escopo o interêsse geral. É a regra a que está sujeita tôda autoridade administrativa. Disto resulta que o desvio de poder é uma causa de ilegalidade suscetivel de afetar todos os atos administrativos, sem exceção alguma" (José Cretella Júnior, Do desvio de poder, p. 57).

63 Nesse sentido, Carmen Chinchilla Marin, ob. cit., pp. 83-90. 
não sendo finalidade da regra repressiva em causa desagregar um núcleo familiar, o ato que o dissolvesse corresponderia à 'utilização de uma competência com fim diverso daquele em vista do qual foi instituída', ou seja, incidiria em desvio de poder. ${ }^{64}$

\subsubsection{Natureza do desvio de poder: vício de legalidade}

O desvio de poder é, como se conceituou acima, o exercício de uma competência administrativa tendo em mira finalidade diversa da que lhe corresponde segundo o comando legal. É dizer, é um vício que decorre da inobservância de um comando legislativo, qual seja, o que determina à Administração Pública que busque o atendimento de um fim específico no exercício da competência que lhe é outorgada.

Trata-se, portanto, de ofensa à lei, e justamente no ponto que the é mais relevante, que revela o seu espírito e razão de ser no ordenamento jurídico: a finalidade. Sendo assim, salta aos olhos que o desvio de poder é um vício de legalidade. ${ }^{65}$

É certo que a violação à lei, no desvio de finalidade, é menos óbvia da que ocorre nos casos de incompetência ou vício de conteúdo do ato administrativo. É que a finalidade legal, que invariavelmente é um interesse público, nem sempre é muito clara, como já foi referido no presente estudo. Por essa razão é comum a afirmação de que o desvio de finalidade atinge o espírito da lei, demonstrando a idéia de fluidez que se confere ao elemento teleológico do ato administrativo.

Bem por isso foi defendido na França, em certo período, que o desvio de poder seria na verdade um vício de moralidade, e não de legalidade. Foi Maurice Hauriou o principal defensor de tal idéia, seguida e desenvolvida por Welter. Ensinava Hauriou, com efeito:

Le véritable cas de détournement de pouvoir, c'est l'excès de pouvoir dans l'exercice du pouvoir discrétionnaire. On comprend par là que l'ouverture du détournement de pouvoir ne se confonde pas avec celle de la violation de la loi. La loi ne peut jamais lier entièrement le pouvoir discrétionnaire, celui-ci ne peut être entièrement lié que par la moralité administrative. (...) L'esprit général de la loi administrative n'est pas autre chose que la moralité administrative, de même que l'esprit général de la loi civile n'est pas autre chose que la moralité privée. ${ }^{66}$

64 Discricionariedade e controle jurisdicional, p. 72.

65 "El vicio de desviación de poder es um vicio de estricta legalidad. Lo que se controla a través de esta técnica es el cumplimiento del fin concreto que señala la norma habilitante y esse control se realiza mediante criterios juridicos estrictos y no mediante reglas morales" (Eduardo García de Enterría, ob. cit., p. 459).

66 Ob. cit., pp. 455-456. M. Welter, em tese na qual desenvolveu a idéia de Hauriou, foi ainda mais claro: "Le contrôle de la moralité administrative n'est plus une appréciation de légalité 
De acordo com a tese defendida por Hauriou, portanto, a violação ao espírito da lei, que seria a marca do desvio de finalidade, não se confundiria com a própria violação à lei. Tal concepção seria, em suas palavras, um abuso "de la notion de la violation de la loi" . ${ }^{67}$ Tratar-se-ia de uma violação à moralidade administrativa, coisa bem diversa, segundo o autor, da ilegalidade.

A concepção de que o desvio de finalidade seria um controle da moralidade administrativa foi rechaçada pela doutrina francesa mais moderna. Jean Rivero chegou a afirmar que a tese defendida por Hauriou representava "uma visão muito estreita" da legalidade. ${ }^{68}$

Dúvida não há de que a tese defendida por Hauriou é juridicamente insustentável, e, ademais, perigosa.

Insustentável porque parte de uma concepção estreita da legalidade e de sua relação com a finalidade. Ora, a finalidade é uma das facetas da legalidade do ato administrativo. A lei que outorga competência à Administração Pública tem em mira um específico interesse público, eleito no exercício da função legislativa, e que deve ser necessariamente objetivado através da edição do ato administrativo. Sendo exercida a competência visando à finalidade diversa da legal, a lei é contrariada de modo frontal, e justamente em aspecto de grande relevância, que é o teleológico, razão de ser do diploma legal, ou seu espírito, para utilizar expressão do próprio Hauriou.

A ofensa ao espírito da lei é uma forma de ilegalidade, talvez até mais grave do que as demais, muito embora mais sutil. É a opinião de Marcel Waline:

En réalité, le détournement de pouvoir permet de sanctionner des violations de l'esprit de la loi qui respectent la lettre de celle-ci. C'est la application de l'idée que 'la lettre tue et l'esprit vivifie': le esprit doit être préféré à la lettre dans l'interprétation d'une loi. Mais la violation de l'esprit d'une loi est encore une violation de la loi; ainsi, le détournement de pouvoir est encore une forme d'illégalité. ${ }^{69}$

Deve-se mencionar, ainda, a inaceitável confusão entre Moral e Direito, na qual se assenta a doutrina ora criticada. Para o jurista, a atividade dos agentes administrativos deve ser pautada pela legalidade, razão pela qual, sob a ótica da ciência do direito, uma determinada conduta é lícita ou ilícita. Tertium non datur. ${ }^{70}$ Daí serem

puisque le but n'est pas examiné à la seule lumière de la disposition légale. (...) Il existe donc à côté de la légalité des mesures administratives, sanctionée par le recours pour violation de la loi proprement dit, une moralité administrative sanctionée notamment par le recours pour détournement de pouvoir" (Le contrôle jurisdictionnel et la moralité administratif, tese, Nancy, 1929, pp. 73 e 75, apud Christian Pelletier, L'appreciation de la légalité des actes administratifs par le juge repressif, pp. 142-143).

67 Idem, p. 456.

68 Ob. cit., p. 290.

69 Ob. cit., p. 426.

70 Ao criticar a teoria do espaço jurídico inexistente, defendida por Santi Romano, ensina o jurista italiano Norberto Bobbio: " a primeira impressão de que uma liberdade juridicamente irrelevante 
inaceitáveis as teses de que "la loi ne peut jamais lier entièrement le pouvoir discrétionnaire, celui-ci ne peut être entièrement lié que par la moralité administrative", ${ }^{71}$ ou de que "le contrôle de la moralité administrative n'est plus une appréciation de légalité puisque le but n'est pas examiné à la seule lumière de la disposition légale". ${ }^{72}$

Não quer isso dizer que a moralidade seja irrelevante para a ciência do direito. Sua importância, entretanto, ao menos para o jurista, decorre exclusivamente de sua inserção no ordenamento jurídico. Afigure-se o exemplo brasileiro: a Constituição Federal, em seu art. 37, consagra o princípio da moralidade. Em função de tal previsão constitucional, os agentes estatais estão juridicamente obrigados a exercer suas competências em acordo com valores eticamente aceitáveis. Mas isso ocorre porque a moralidade administrativa, no ordenamento pátrio, é princípio jurídico. Citem-se as palavras de Celso Antônio Bandeira de Mello, que a propósito do princípio da moralidade administrativa ensina o seguinte:

De acordo com ele, a Administração e seus agentes têm de atuar na conformidade de princípios éticos. Violá-los implicará violação ao próprio direito, configurando ilicitude que assujeita a conduta viciada a invalidação, pois tal princípio assumiu foros de pauta jurídica, na conformidade do art. 37 da Constituição. ${ }^{73}$

A concepção defendida por Hauriou é, ademais, perigosa, pois pode ser utilizada como argumento para mitigar o controle jurisdicional da finalidade do ato administrativo, já que tal controle funda-se na legalidade. O magistrado verifica a compatibilidade do ato administrativo em face do ordenamento jurídico. Se a finalidade é considerada não um elemento da legalidade, mas sim da moralidade, não há espaço para o exercício da função jurisdicional no controle desse importante aspecto do ato administrativo.

não exista nasce do fato de que Romano, para definir essa liberdade e para distingui-la da liberdade jurídica (considerada como esfera do lícito) chama-a de esfera daquilo que nāo é nem lícito e nem ilícito. Ora, como lícito e ilícito são dois termos contraditórios, não podem excluir-se mutuamente, porque, se não podem ser ambos verdadeiros, não podem também ser ambos falsos. E, portanto, não pode existir uma situação que não seja ao mesmo tempo nem lícita nem ilícita" ( $A$ teoria do ordenamento jurídico, p. 130).

71 Maurice Hauriou, ob. e loc. citados.

72 M. Welter, ob. e loc. citados.

73 Curso de direito administrativo, p. 89. Vale ser transcrita, no mesmo sentido, a lição de Marçal Justen Filho sobre o princípio da moralidade administrativa: "Essa concepção não implica afirmar a identidade entre Direito e Moral. A tese envolve reconhecimento de que o ordenamento jurídico impõe a compatibilidade da conduta do agente público com determinados parâmetros éticos. A existência de um princípio jurídico da moralidade significa que algumas valorações morais do grupo são recepcionadas pelo Direito Público" ( $O$ princípio da moralidade pública e o direito tributário, p. 45). 
Isso ocorreu na França, fato lamentado pelo próprio Welter, paladino da tese que identifica a finalidade com a moralidade, em passagem de sua obra que não ficou isenta da crítica feroz de Christian Pelletier, como se lê:

Regrets tardifs d'une inconséquence regrettable! Ou bien le détournement de pouvouir est un contrôle de légalité et entre, à ce titre, dans l'excès de pouvoir, ou bien il est un contrôle de la moralité, et, à ce titre, les tribunaux, dont la mission de juger et non d'administrer, ont parfaitement raison de $s^{\prime}$ abstenir de tout contrôle. ${ }^{74}$

O mesmo ocorreu na Espanha, em época bem mais recente, situação comentada de modo muito espirituoso por Santamaría Pastor:

Si se piensa que anular un acto administrativo por desviación de poder equivale poco menos que a llamar immoral y sinvergüenza a la autoridad que lo dictó (lo cual no es en absoluto cierto), no es de extraño que los Tribunales contenciosos que asi razonan se hayan mostrado reticentes a acoger este vicio en sus pronunciamentos. ${ }^{75}$

\subsubsection{Modalidades do desvio de poder}

O fim do exercício da competência administrativa é atender ao interesse público eleito pelo legislador. Daí ser possível afirmar que a finalidade é sempre um interesse público, conforme já explicado. ${ }^{76}$ Também foi mencionado no presente estudo que, por vezes, o interesse público que deve ser atingido pela ação administrativa é especificado pela lei (interesse sanitário, econômico etc). Além do interesse público genérico, portanto, há também um interesse público específico, vinculado à competência administrativa.

Pois bem. Com base em tal distinção entre o interesse público genérico e o interesse público específico a doutrina é unânime em diferenciar duas modalidades do desvio de poder. Na primeira o agente administrativo pratica o ato visando à finalidade totalmente estranha ao próprio interesse público; na segunda, muito embora o interesse visado seja público, é outro que não aquele ligado à competência conferida ao agente administrativo. ${ }^{77}$

74 Ob. cit., p. 143.

75 Renovación dogmática en torno de la desviación de poder como instrumento de control, p. 3.

76 Vale ser novamente transcrita a lição de Queiró: "o fim é, pois, aquêle interêsse público cuja realização a lei tem em vista ao conceder a determinada autoridade certo poder de agir" (A teoria do desvio de poder no direito administrativo, RDA vol. VII, pp. 69-70).

77 "Les modalités selon lesquelles peut se manifester le détournement de pouvoir sont très diverses; on peut cependant les grouper sous deux chefs en distinguant les deux types de but légaux auxquels l'activité administrative doit se conformer: le but d'intérêt général commun à tous les actes administratives; les buts particuliers, propres à chacun d'eux" (André de Laubadère, ob. cit., p. 539). 
Na primeira hipótese o agente competente pratica o ato não para atender o interesse público que fundamenta sua atribuição, mas sim para atingir interesses particulares, seus ou de outros. É o caso do ato praticado para prejudicar terceiros, ou beneficiar o próprio agente e seus comparsas. Enfim, atos inspirados no intuito de perseguir ou de privilegiar, sem que a perseguição ou o privilégio decorram do comando legal. Há aqui um vício de intenção, sendo o móvel do agente censurável. ${ }^{78}$

Se toda competência administrativa é atribuída para possibilitar o atendimento de um interesse público, a primeira modalidade de desvio de finalidade é vício dos mais graves. $O$ agente administrativo descumpre o comando mais básico que deve nortear sua atividade de servidor do Estado, e que caracteriza o regime jurídico administrativo: a supremacia do interesse público sobre o privado. ${ }^{79}$

Já na segunda modalidade do desvio de poder, o agente administrativo não tem em mira interesse particular, mas sim interesse público, diverso, todavia, do interesse público que deve ser alcançado através do ato administrativo praticado.

Como visto, cabe ao legislador eleger os interesses públicos num determinado momento histórico do Estado. Cabe-lhe, ainda, outorgar competências aos agentes administrativos, às quais são ligados interesses públicos específicos. Se o agente competente edita o ato para atingir interesse público diverso daquele que está ligado à sua competência, pratica igualmente desvio de finalidade. Afinal, como ensina Caio Tácito, "não é a qualidade do fim, mas a sua natureza legal que legitima a prática administrativa" ${ }^{80}$ Vale ser invocada, ainda, a preciosa lição da Waline:

Il se peut que le législateur n'ait donné un certain pouvoir à une autorité administrative que pour atteindre un résultat déterminé, et l'usage de ce pouvoir dans tout autre but, même d'intérêt public, est allors illégal. ${ }^{81}$

Exemplo típico da segunda modalidade de desvio de finalidade é a utilização do poder de polícia para aumentar a arrecadação tributária do ente estatal. $O$ aumento da arrecadação do Estado não é, a toda evidência, finalidade de interesse particular, mas sim de interesse público. Nem por isso deixa de se configurar o desvio, pois a competência outorgada à Administração Pública para exercer sua atividade de polícia não se presta a tal fim.

78 Não se deve confundir móvel com motivo do ato administrativo. O primeiro é a intenção do agente que pratica o ato, o objetivo particular que ele tem em mira ao exercer sua competência; o segundo é o pressuposto de fato ou de direito que justifica a edição do ato administrativo. Segundo Marcel Waline, "les motifs sont des faits ayant une existence objective et qui peuvent justifier une décision. Le mobile, au contraire, c'est le sentiment, le désir qui a inspiré l'auteur de l'acte" (ob. cit., p. 417).

79 Sobre o regime jurídico administrativo e, em especial, o princípio da supremacia do interesse público sobre o privado, ver Celso Antônio Bandeira de Mello, Curso de direito administrativo, pp. 30-33.

80 Ob. cit., p. 102.

81 Ob. cit., p. 423. 
A segunda modalidade de desvio de finalidade é igualmente grave, por diversas razões.

Em primeiro lugar porque representa verdadeira usurpação da função legislativa pelo agente administrativo. De fato, se cabe ao legislador outorgar à Administração Pública competência para atingir uma finalidade pública específica, e se tal competência é utilizada visando a outra finalidade pública, na realidade o agente administrativo escolheu qual o interesse público que corresponde aos poderes que lhe foram conferidos, tarefa que ultrapassa os limites da função administrativa. ${ }^{82}$

Em segundo lugar porque coloca em risco a segurança jurídica dos indivíduos, que têm na lei a medida da competência da Administração Pública, inclusive no tocante à finalidade. Se a lei outorga competência ao agente administrativo para o atendimento de uma finalidade específica, os indivíduos têm a segurança de que tal finalidade somente será perseguida através de uma determinada espécie de ato administrativo, editado em uma forma própria e após o trâmite do respectivo - e também específico - procedimento administrativo.

Utilizando a sua competência para atingir outra finalidade pública, o agente administrativo surpreende o particular interessado, praticando ato administrativo sem as formalidades que seriam exigíveis tendo em vista a finalidade legal ligada à competência. E as formalidades, bem se sabe, são um importante limite à arbitrariedade. $^{83}$

Diga-se, ainda, que nessa segunda modalidade do desvio de poder está inserido o détournement de procedure, tão comentado no direito administrativo francês. ${ }^{84}$ Trata-se da utilização de um procedimento inadequado para atingir a finalidade legal, em função de alguma facilidade que decorre para a Administração Pública da não utilização do procedimento correto.

A questão é de grande importância, pois o procedimento é uma das garantias do indivíduo frente aos órgãos estatais. Estabelecido um procedimento para atingir

82 "Não é facultado, em suma, ao administrador substituir o legislador, criando para a regra de competência quaisquer fins que lhe pareçam mais consentâneos, ou que, maliciosamente, introduza em detrimento da verdadeira finalidade" (Caio Tácito, ob. cit., p. 89).

83 "Repise-se que no Estado de Direito é garantia do administrado saber que o poder público está adstrito não só aos fins que de antemão a lei elegeu como prezáveis, mas também aos meios que adrede categorizou como sendo os próprios para suprir as finalidades consideradas valiosas tanto mais porque, nos tempos modernos, rara é a finalidade que não se inclua dentro do campo de objetivos que o Estado se propõe a tutelar" (Celso Antônio Bandeira de Mello, Discricionariedade e controle jurisdicional, pp. 65-66).

84 Segundo Laubadère, tratando do tema do détournement de procedure, "il peut arriver q'un même résultat puisse être atteint au moven de deux procédures organisées différemment et ayant chacune ses conditions propres d'application; le détournement de pouvoir apparaitra ici lorsque l'administration cherchera à employer l'une des deux procédures à la place de l'autres alors que les conditions d'emploi de la premiére ne sont pas réunies mais parce qu'elle présentera pour elle des avantages et afin d'en profiter" (ob.cit., p. 541). Ver ainda, Marcel Waline, ob. cit., pp. 423-424; Jean Rivero, ob. cit., p. 291; René Chapus, ob. cit., pp. 1.031-1.032. 
uma determinada finalidade, a utilização de outro, menos gravoso para a Administração Pública, constitui lesão ao direito dos particulares interessados. ${ }^{85}$

A existência dessa segunda modalidade do desvio de finalidade coloca uma pá de cal sobre a tese de que o desvio de finalidade seria vício de moralidade, tal qual defendido por Hauriou. Não há, aqui, nada que se possa repreender do ponto de vista moral: o agente exerceu sua competência para atender o interesse público, mas não aquele interesse cujo atendimento lhe fora atribuído pela lei. Daí concluir André de Laubadère, ao tratar da tese de Hauriou:

Ce point de vue ne peut être retenu. Outre qu'il comporte confusion entre la morale et le droit, il tend à limiter le détournement de pouvoir aux hypothèses où l'auteur de l'acte administratif a agi avec une intention malveillante, de mauvaise foi; or, ce ne sont pas là les seuls cas de détournement de pouvoir; celui-ci se présente souvent sous la forme de l'emploi incorrect d'une procédure là où une autre procédure aurait dû être utilisée sans qu'il y ait eu de mauvaise foi ou d'immoralité dans l'agissement administratif. ${ }^{86}$

\subsubsection{O problema da intencionalidade do agente}

Há quem sustente que o desvio de poder é um vício subjetivo, que se configura nas hipóteses em que o agente administrativo deliberadamente exerce sua competência visando a atingir finalidade diversa da legal, seja com vistas a interesse privado, seja com vistas a interesse público diverso daquele que é tutelado pela norma aplicada. ${ }^{87} \mathrm{Ou}$ seja, o problema do desvio de finalidade residiria no móvel do agente, já que para sua configuração haveria a necessidade de que a intenção fosse sempre viciada.

Com base nas idéias até aqui expostas é intuitivo que se rejeite a tese mencionada. O vício do desvio de poder, embora seja decorrência, muitas vezes, de um vício no móvel do agente administrativo, nem sempre o é. Bem por isso parece mais acertado afirmar que o vício, na realidade, é objetivo. Vejamos.

85 A importância fica ainda mais evidente se se tiver em mente o fato de que todo ato administrativo, já que oriundo do exercício de função estatal, decorre de um procedimento, na lição de Carlos Ari Sundfeld: “como a 'vontade' manifestada pelo Estado, na produção de seus atos (sejam legislativos, administrativos ou jurisdicionais), traduz sempre o exercício de função, segue-se que o processo é o modo normal de agir do Estado. Em outras palavras: a realização do processo é indispensável à produção ou execução dos atos estatais" (Fundamentos de direito público, p. 166).

86 Ob. cit., p. 539.

87 "La primera nota que caracteriza a esa conducta de la Administración [desvio de poder] es su voluntariedad o intencionalidad, esto es, el apartamiento del fin es querido y buscado por la Administración autora del acto (...) La esencia de la desviación de poder está precisamente ahí, en que la potestad se ejerce con la intención de servir a un fin distinto al que la legitima y que es la causa o razón del acto" (Carmen Chinchilla Marin, ob. cit., p. 118). 
Foi sustentado, com amparo na doutrina mais moderna do direito administrativo, que o desvio de finalidade é um vício de estrita legalidade. Ou seja, ao se afastar da finalidade ligada à sua competência, o agente administrativo contraria a lei, ofende o ordenamento jurídico. Em suma, age de modo ilícito.

Ora, o descompasso entre a finalidade visada pela norma jurídica e a finalidade do ato administrativo concreto pode ocorrer com ou sem a intenção do agente. É dizer, o móvel viciado não é essencial para que se configure o apartamento entre o exercício da competência administrativa e a finalidade legal. Pode ocorrer que o agente administrativo aja de boa fé e, ainda assim, pratique ato que não se coaduna com a finalidade específica vinculada à sua competência. Da mesma forma, é possível que o agente, com as piores intenções imagináveis, pratique ato administrativo que não padeça de vício algum em relação à finalidade, mormente nos casos de competência estritamente vinculada.

Enfim, importa é o fato objetivo de ter sido a finalidade legal desrespeitada, e não o móvel do agente. Afinal, na pena precisa do jurista gaúcho Ruy Cirne Lima, "o fim - e não a vontade, - domina todas as formas de administração" ${ }^{88}$ Isso porque, como ensina Celso Antônio Bandeira de Mello:

No direito público, a satisfação do escopo sobreleva a boa ou má intenção do sujeito que pratica o ato. Se o atendeu com bons ou maus propósitos, nada importa. Se o desatendeu com intentos lisos ou incorretos, praticou, igualmente, uma ilegalidade e o ato não pode prosperar. ${ }^{89}$

Considerar o desvio de finalidade um vício subjetivo é uma reminiscência indesejada da antiga e já superada concepção de que a finalidade não seria um aspecto da legalidade do agir administrativo, mas sim de sua moralidade. Tratando-se de um problema ético, importava verificar a intenção do agente, seu móvel viciado, que deliberadamente conspurcava a competência administrativa que o legislador the havia conferido. Aí sim fazia sentido considerar o desvio de finalidade um vício subjetivo.

Mas com a concepção mais moderna, segundo a qual o desvio de finalidade é vício de estrita legalidade, a intenção do agente perde relevância para a configuração do vício (não para sua averiguação). Releva, isso sim, verificar o efetivo apartamento entre o exercício da competência administrativa e a finalidade legal. E nada mais. "Lo que está en juego", já disse García de Enterría, "es la legalidad administrativa y no la moralidad del funcionario o de la propia Administración". ${ }^{90}$

88 Ob. cit., p. 22.

89 Discricionariedade e controle jurisdicional, p. 73.

90 Ob. cit., pp. 459-460. E continua o mestre da Universidade Complutense de Madrid: "por eso, precisamente, es por lo que la desviación de poder no se reduce a los supuestos en que el fin realmente perseguido es un fin privado del agente, sino que se extiende, como ya se ha dicho, a todos los casos en que, abstracción hecha de la conducta del agente, es posible constatar la 
A intenção do agente será relevante para a investigação do desvio de finalidade, em especial nos casos de competência discricionária - que são a grande maioria, reconheça-se. De fato, havendo discricionariedade, em especial na delimitação da própria finalidade legal, o desvio de poder apenas pode ser deduzido do móvel viciado do agente, pois não se terá elementos para averiguar se a finalidade do ato administrativo destoou ou não do comando legal. $O$ vício da intenção, em tais hipóteses, gera a presunção juris et de jure de que houve vício de finalidade. $\mathrm{O}$ primeiro vício implica o segundo.

Note-se bem: o desvio de finalidade continua sendo um vício objetivo, que decorre do apartamento entre o exercício da competência administrativa e a finalidade consagrada na lei. A intenção viciada do agente é apenas indicativo de que tal apartamento ocorreu. ${ }^{91}$

\subsection{A prova do desvio de poder}

A grande dificuldade do controle jurisdicional do desvio de poder assenta na prova da ocorrência do vício. ${ }^{92}$ Em geral, como visto, o desvio de finalidade decorre da intenção viciada do agente detentor de competência discricionária. Em tais casos, é preciso analisar o móvel do agente, tarefa árdua porque quanto mais grave for o desvio, mais dissimulado será o agente. ${ }^{93}$

A primeira dificuldade que se apresenta ao magistrado confrontado com uma alegação de desvio de finalidade é a apuração da finalidade legal, ou seja, do interesse público que deve ser o alvo da competência administrativa.

Já foi mencionado que nem sempre a norma é clara e precisa ao determinar o interesse público específico que consubstancia a finalidade da competência administrativa. Se a lei é objetiva em alguns casos, não o é em outros, podendo mesmo ser omissa, hipótese em que o interesse público estará definido de modo implícito. ${ }^{94}$

existencia de una divergencia entre los fines realmente perseguidos y los que, según la norma aplicable, deberían orientar la decisión administrativa" (idem, p. 460).

91 "O que faz inválido o ato nestes casos é efetivamente seu descompasso com o escopo legal, porém tal descompasso é deduzido do fato do agente não haver direcionado sua conduta ao escopo devido. Em rigor, haverá presunção, juris et de jure, de que a intençāo incorreta desemboca em desacordo do ato com seu fim próprio" (Celso Antônio Bandeira de Mello, Discricionariedade e controle jurisdicional, p. 74).

92 Sobre a relação entre prova e direito administrativo, é muito interessante a seguinte passagem do jurista francês Lavau: "il n'y a pas en droit de pouvoir discrétionnaire au profit de l'Administratión, mais c'est l'insuffisance du régime des preuves dans la procédure du Conseil d'État, qui en fait, lui confere une puissance discrétionnaire" (G. E. Lavau, Le prétendu pouvoir discrétionnaire d'exclure un candidat d'un concours administratif, J. C. P., 12/1 1/1953, I, 1.128, apud Jeanne Lemasurier, La preuve dans le détournement de pouvoir, p. 36).

93 "En effet, lorsqu'une autorité administrative commet un détournement de pouvoir, elle est souvent de mauvaise foi; elle sait fort bien qu'elle trahit l'intention du législateur; aussi n'a-t-elle pas la nä̈veté d'indiquer les raisons inavouables qui ont inspiré son acte; elle dissimule ses véritables mobiles, que le juge doit alors rechercher d'après toutes les circonstances dans lesquelles l'acte a été pris; et cette preuve est très difficile à faire" (Marcel Waline, ob. cit., p. 418). 
Sendo imprecisa a finalidade, deve o magistrado interpretar a norma que outorgou competência à Administração Pública através dos critérios de hermenêutica consagrados. Deve, principalmente, atentar para a natureza da competência, que indicará, ao menos de modo genérico, qual a finalidade da competência administrativa. Assim, ainda que seja silente quanto à finalidade norma jurídica que outorgue a agente administrativo o exercício de poder de polícia, a natureza de tal competência permitirá ao magistrado deduzir, p. ex., que o aumento de arrecadação tributária extrapola o seu papel. ${ }^{95}$

A determinação da finalidade legal do ato administrativo é de extrema relevância para o controle do desvio de poder, pois pode ser suficiente para que o magistrado conclua pela ocorrência do vício e conseqüente anulação do ato. Com efeito, a prova do desvio de poder é negativa: é preciso provar que a finalidade legal não foi perseguida, não sendo necessária a prova da real finalidade do agente. Ou seja, para que se prove a ocorrência do desvio de finalidade, basta a demonstração de que o ato não foi praticado para atingir a finalidade prevista na norma jurídica. ${ }^{96}$

Tal possibilidade - não provar a finalidade do agente ao exercer sua competência - decorre da concepção adotada no presente trabalho, segundo a qual o desvio de finalidade é um vício objetivo de estrita legalidade. Sendo assim, não se torna necessário demonstrar qual o fim que foi efetivamente visado pelo agente administrativo, sendo suficiente que se demonstre que a finalidade legal não foi atendida.

Se tal possibilidade pode atenuar o problema da prova do desvio de poder em alguns casos, não a elimina. Afinal, como já dito e repetido, em muitas hipóteses, mormente de competência discricionária, o vício apenas é demonstrado através do móvel desviado do agente. $O$ desvio de finalidade, em tais situações, é uma presunção juris et de jure da intenção viciada, o que não o torna, absolutamente, um vício subjetivo. ${ }^{97}$

94 Renato Alessi, ob. cit., pp. 236-237.

95 "Le juge de l'excès de pouvoir déduit de la nature même de la competénce exercée les buts licites de cette compétence. L'exemple type est celui du pouvoir de police, qui, de par sa nature, ne peut être exercé qu'en vue d'un but de sécurité, tranquillité ou salubrité et non en vue de tel autre but d'intérêt général, par exemple d'un but financier" (André de Laubadère, ob. cit., p. 541). 96 "No siempre es fácil concretar el interés público que la norma ha establecido como objetivo a perseguir por el acto, juzgando las intenciones de la Administración, que ésta buscó conscientemente no atender al mismo, no debe exigirse también al administrado que concrete cuál era el fin al que quería realmente servir: si un fin público, pero distinto a aquél; si favorecer a una persona, si vengarse de otra, etc. Ello, además de difícil, puede resultar, en la mayoria de los casos, innecesario" (Carmen Chinchilla Marin, ob. cit., p. 128).

97 " $O$ vício subjetivo não é a razão jurídica pela qual o ato é invalidado, mas é a razão bastante para depreender-se que, por força dele, se desencontrou com a finalidade a que teria de aceder" (Celso Antônio Bandeira de Melio, Discricionariedade e controle jurisdicional, p. 74). Repise-se: a invalidade do ato decorre, sem exceção, do apartamento entre a finalidade legal e o exercício da competência. 
Tem-se então uma nova dificuldade: apurar a real intenção do agente administrativo que exerceu a competência administrativa.

A análise da jurisprudência do Conselho de Estado francês mostra interessante evolução em tal tópico. Jeanne Lemasurier, autora de trabalho clássico sobre o tema, identifica quatro fases em tal evolução. Na primeira fase, a prova deve resultar unicamente dos termos do ato administrativo que se pretende tenha sido praticado com desvio de finalidade; "le libellé des articles et l'ensemble de ses dispositions devaient faire apparaître l'illegalité du but poursuivi par son auteur". ${ }^{98} \mathrm{Na}$ segunda, a prova deve ser colhida em todos os atos que integrem o procedimento administrativo que deu origem ao ato administrativo impugnado; o magistrado "examinera, par exemple, la correspondance, qui a précédé ou suivi l'acte attaqué, de même que les instructions des supérieurs hiérarchiques, en vertu desquelles la mesure a été prise". 99

Até então o Conselho de Estado francês admitia que a prova do desvio de finalidade decorresse tão-somente do próprio ato impugnado e do seu respectivo procedimento administrativo. Percebe-se, com clareza, que sob tais restrições pouco poderia ser feito no tocante à prova do desvio.

A terceira e quarta fase mencionada por Lemasurier representam o verdadeiro avanço, que tornou efetivo o controle do desvio de finalidade. Na terceira, a jurisprudência francesa passa a admitir que a prova decorra de presunções extraídas dos elementos do procedimento, como tempo e lugar em que foi o ato praticado. Finalmente, na quarta fase, o Conselho de Estado admite que a prova resulte de circunstâncias exteriores ao litígio, mesmo que relacionadas a outros sujeitos que não os atingidos pelo ato impugnado. ${ }^{100}$

$O$ avanço da jurisprudência do Conselho de Estado francês resulta da percepção de que a efetividade do controle do desvio de finalidade não é viável se forem exigidas provas contundentes da ocorrência do vício. Ao admitir que a prova do desvio decorra de presunções e circunstâncias externas ao ato administrativo, o Conselho de Estado francês abandonou o formalismo e tornou o controle do desvio de finalidade um meio efetivo de se obstar a arbitrariedade da Administração Pública.

De fato, a investigação do móvel do agente não permite, com raras exceções, que se chegue a uma prova contundente do desvio de finalidade. Por se tratar justamente de elemento altamente subjetivo, exigir prova cabal do vício do móvel significa relegar o desvio de finalidade a uma figura sem nenhuma relevância prática.

Daí assentar a doutrina que é suficiente para a prova do desvio de finalidade a existência de indícios que formem a conviç̧ão de que o agente exerceu sua competência tendo em vista fim outro que o interesse público específico tutelado pela

98 Ob. cit., p. 59.

99 Idem, p. 60.

100 Ibidem, pp. 61-65. 
norma jurídica. "La preuve du détournement de pouvoir résulte d'une conviction, non d'une constatation". ${ }^{101}$ Sobre o tema ensina García de Enterría:

"Facilmente se comprende que esta prueba no puede ser plena, ya que no es presumible que el acto viciado confiese expresamente que el fin que lo anima es otro distinto del señalado por la norma. Consciente de esta dificultad, así como de que la exigencia de un excesivo rigor probatorio privaría totalmente de virtualidad a la técnica de la desviación de poder, la mejor jurisprudencia suele afirmar que para que pueda declararse la existencia de esa desviación es suficiente la convicción moral que se forme el Tribunal." 102

Os indícios podem ser os mais variados. Podem ser citados os seguintes: a ilogicidade do ato, a irrazoabilidade, a desproporcionalidade, o rompimento de uma cadeia de atos habitualmente editados pela Administração Pública, a contradição e insuficiência da motivação etc. ${ }^{103}$ Deve-se mencionar ainda a quebra da isonomia, indício dos mais contundentes da ocorrência do desvio de finalidade. Se o ato administrativo nega algo que a outros interessados, nas mesmas circunstâncias, é conferido, muito provavelmente é editado com finalidade vedada pela lei, qual seja, a de discriminar.

Diga-se, por fim, que o papel do magistrado no controle do desvio de finalidade, e em especial no tocante à produção da prova do vício, não pode ser o de mero espectador, que aguarda que as personagens principais desenvolvam a trama perante seus olhos. O processo judicial tem funções próprias - sociais, jurídicas e políticas -, que não são condizentes com a figura de um simples árbitro desinteressado. ${ }^{104}$ Quando mais em casos como o do desvio de finalidade, que representa uma odiosa arbitrariedade que afronta os princípios mais basilares de nosso ordenamento juridico.

É patente que o indivíduo, na grande maioria das vezes, não dispõe de todos os meios para provar a ocorrência do desvio de finalidade. Mesmo porque a própria Administração Pública pode sonegar os elementos necessários à demonstração, p.

101 Jeanne Lemasurier, ob. cit., p. 43. Jean Rivero, comentando a postura mais moderna do Conselho de Estado francês, aduz que o mesmo, no controle do desvio de finalidade, "procura menos uma prova manifesta que uma conviç̧ão, que pode resultar de um 'feixe de indícios convergentes"' (ob. cit., p. 292). Vale ainda ser transcrita a lição de Carnelutti: "Il vero è che l'eccesso di potere $\grave{e}$ un vizio occulto dell'atto, non un vizio apparente; è come una malattia, della qualle la diagnosi non si può far quasi mai (oserei togliere forse anche il 'quasi') direttamente, ma soltanto per sintomi" (ob. cit., p. 48).

102 Ob. cit., p. 460.

103 Ver, a propósito, Celso Antônio Bandeira de Mello, Discricionariedade e controle jurisdicional, p. 80; Renato Alessi, ob. cit., p. 421.

104 Sobre as funções do processo, ver Cândido Rangel Dinamarco, A instrumentalidade do processo, pp. 149 e ss. 
ex., de que a orientação adotada no caso concreto é divergente da habitualmente acolhida pelo mesmo agente administrativo (quebra da isonomia), fato que demandaria acesso a um grande número de documentos internos da própria Administração.

Assim, é preciso que o juiz utilize os poderes de que dispõe para investigar o ato administrativo impugnado, abandonando o mito do ônus da prova e exigindo da Administração Pública que apresente todos os documentos que se mostrem relevantes para o desfecho do caso concreto trazido ao Poder Judiciário. Tal atuação é a mais condizente com a moderna doutrina do direito processual civil, ${ }^{105}$ e, sem sombra de dúvidas, com o ordenamento jurídico de um Estado Democrático de Direito.

\section{Conclusão}

1. De acordo com o critério formal, único relevante para a ciência do direito, já que leva em consideração o regime jurídico, a função administrativa pode ser definida como a atividade estatal infralegal que visa ao atendimento dos interesses públicos eleitos pelo legislador, cujos atos são passíveis de controle pelo Poder Judiciário. Tal conceito não é intemporal e universal. Decorre do ordenamento jurídico pátrio, em especial das seguintes disposições constitucionais: art. $5^{\circ}$, incisos II e XXXV, art. 37, caput, art. 84, inciso IV.

2. A finalidade do ato administrativo é o objetivo que o exercício da competência deve ter em mira, de acordo com o comando legal. Será sempre um interesse público, mais ou menos detalhado pelo legislador. Sendo a finalidade veiculada através de conceito jurídico indeterminado, pode dar ensejo à discricionariedade administrativa, tão-somente na zona de incerteza do conceito utilizado pelo legislador.

3. Desvio de poder (ou de finalidade) é o exercício de uma competência administrativa tendo em mira finalidade diversa da que lhe corresponde segundo o comando legal. $O$ ato administrativo maculado pelo desvio de poder é inválido, não sendo passível de convalidação.

4. O desvio de finalidade é uma criação do Conselho de Estado francês, que ampliou o conceito de excès de pouvoir para abranger o controle da finalidade do ato administrativo. No Brasil, deve-se a Seabra Fagundes a inserção mais aprofundada do desvio de finalidade, tanto na doutrina como na jurisprudência.

5. O desvio de poder é praticado por agente competente, que utiliza os poderes que lhe foram outorgados pela lei para atingir finalidade estranha ao comando legal. Tanto os atos decorrentes de competência discricionária como os de competência vinculada podem ser praticados com desvio de finalidade.

6. É o desvio de poder um vício de estrita legalidade, que atinge um dos aspectos legais da competência administrativa, a saber, a finalidade. A tese que sustenta ser um vício de moralidade, outrora defendida na França, deve ser rejeitada.

105 Ver, a propósito, José Carlos Barbosa Moreira, $O$ juiz e a prova; José Roberto dos Santos Bedaque, Poderes instrutórios do juiz, em especial pp. 84-91. 
7. Há duas modalidades de desvio de finalidade. Na primeira, o agente administrativo exerce sua competência tendo em mira finalidade totalmente estranha ao interesse público. $\mathrm{Na}$ segunda, a finalidade do ato administrativo praticado é um interesse público, mas diverso daquele que presidiu a outorga da competência ao agente.

8. O desvio de finalidade é um vício objetivo, que consiste no apartamento entre o exercício da competência administrativa e a finalidade legal. A intenção do agente não é relevante para a configuração do vício, mas apenas para sua averiguação, mormente nos casos de competência discricionária. Em tais casos, o móvel viciado gera presunção juris et de jure da ocorrência do desvio de finalidade.

9. A prova do desvio de finalidade é negativa: basta demonstrar que a finalidade legal não foi objetivada pelo exercício da competência, sendo desnecessária a prova de qual a finalidade efetivamente buscada pelo agente. Sendo necessária a investigação do móvel do agente, em especial nos casos de competência discricionária, não se deve exigir prova contundente do vício, sob pena de se tornar o desvio de finalidade figura sem nenhuma relevância prática. Deve-se recorrer a indícios que levem a uma convicção de que o agente teve em mira finalidade outra que a legal.

Referências bibliográficas

ALESSI, Renato. Principi di diritto amministrativo. 4. ed., Milão: Giuffrè, 1978, vol. I.

AMARAL, Antônio Carlos Cintra do. Extinção do ato administrativo. São Paulo: Revista dos Tribunais, 1978.

ARISTÓTELES. A política. Trad. Nestor Silveira Chaves. São Paulo: Atena, s/d.

BANDEIRA DE MELLO, Celso Antônio. Discricionariedade e controle jurisdicional. 2. ed., 3. tir., São Paulo: Malheiros, 1998.

"Relatividade" da competência discricionária. In: Revista trimestral de direito público. São Paulo: Malheiros, v. 25, pp. 13-19, 1999.

Curso de direito administrativo. 12. ed., São Paulo: Malheiros, 2000.

BANDEIRA DE MELLO, Oswaldo Aranha. Princípios gerais de direito administrativo. 2. ed., Rio de Janeiro: Forense, 1979, v. I.

BARBOSA MOREIRA, José Carlos. $O$ juiz e a prova. In: Revista de processo. São Paulo: Revista dos Tribunais, n. 35, pp. 178-184, jul./set. 1984.

BEDAQUE, José Roberto dos Santos. Poderes instrutórios do juiz. 2. ed., São Paulo: Revista dos Tribunais, 1994.

BÉNOIT, Francis-Paul. Le droit administratif français. Paris: Dalloz, 1968.

BISCARETTI DI RUFFIA, Paolo. Diritto costituzionale. 2. ed., Napoli: Eugenio Jovene, 1949, v. I.

BOBBIO, Norberto. Teoria do ordenamento jurídico. Trad. Maria Celeste Cordeiro Leite dos Santos. 5. ed., Brasília: UnB, 1994.

CARNELUTTI, Francesco. Eccesso di potere. In: Rivista di diritto processuale civile. Padova: Cedam, vol. I, pp. 33-55, 1924. 
CAVALCANTI, Themístocles. Tratado de direito administrativo. 2. ed., Rio de Janeiro: Freitas Bastos, 1948, vol. II.

. Tratado de direito administrativo. 2. ed., Rio de Janeiro: Freitas Bastos, 1951, vol. VI.

CHAPUS, René. Droit administratif général. 14. ed., Paris: Montchrestien, 2000, t. I.

CLÈVE, Clèmerson Merlin. Atividade legislativa do Poder Executivo. 2. ed., São Paulo: Revista dos Tribunais, 2000.

CRETELLA JÚNIOR, José. Do desvio de poder. São Paulo: Revista dos Tribunais, 1964.

CUOCOLO, Fausto. Istituzioni di diritto pubblico. 10. ed., Milão: Giuffrè. 1998.

DINAMARCO, Cândido Rangel. A instrumentalidade do processo. 6. ed., São Paulo: Malheiros, 1998.

DUGUIT, Léon. L'État. Paris: Albert Fontemoing, 1901, t. I.

Traité de droit constitutionnel. 2. ed., Paris: Boccard, 1923, t. II.

ENGISCH, Karl. Introdução ao pensamento jurídico. Trad. João Baptista Machado. 5. ed., Lisboa: Calouste Gulbenkian, 1965.

FAGUNDES, Seabra. $O$ contrôle dos atos administrativos pelo Poder Judiciário. Rio de Janeiro: Freitas Bastos, 1941.

O controle dos atos administrativos pelo Poder Judiciário, 4. ed., Rio de Janeiro: Forense, 1967.

FIGUEIREDO, Lucia Valle. Curso de direito administrativo. 4. ed., São Paulo: Malheiros, 2000.

FRAGOLA, Umberto, Gli atti amministrativi. 2. ed., Napoli: Eugenio Jovene, 1964. GARCÍA DE ENTERRÍA, Eduardo; FERNÁNDEZ, Tomás-Ramón. Curso de derecho administrativo. 8. ed., Madri: Civitas, 1997, vol. I.

HAURIOU, Maurice. Précis de droit administrative et de droit public. 10. ed., Paris: Recueil Sirey, 1921.

JUSTEN FILHO, Marçal. O princípio da moralidade pública e o direito tributário. In: Revista trimestral de direito público. São Paulo: Malheiros, v. 11, pp. 44-58, 1995.

KELSEN, Hans. A teoria pura do direito. Trad. João Baptista Machado. 4. ed., Coimbra: Armênio Amado, 1979.

LAUBADÈRE, André de; VENEZIA, Jean-Claude; GAUDEMET, Yves. Traité de droit administratif. 14. ed., Paris: LGDJ, 1996, t. I.

LEAL, Victor Nunes. Problemas de direito público. Rio de Janeiro: Forense, 1960.

LEMASURIER, Jeanne. La preuve dans le détournement de pouvoir. In: Revue du droit public et de la science politique en France et a l'étranger. Paris: LGDJ, pp. 36-66, 1959.

LIMA, Ruy Cirne. Princípios de direito administrativo. 5. ed., São Paulo: Revista dos Tribunais, 1982.

MARIN, Carmen Chinchilla. La desviación de poder. 2. ed., Madri: Civitas, 1999.

MEIRELLES, Hely Lopes. Direito administrativo brasileiro. 21. ed. (atualizada por Eurico de Andrade Azevedo, Délcio Balestero Aleixo e José Emmanuel Burle Filho), São Paulo: Malheiros, 1996. 
MONTESQUIEU, Charles de. El espiritu de las leyes. Trad. de Nicolás Estévanez. Buenos Aires: Libertad, s/d.

MORENO, Fernando Sainz. Reducción de la discrecionalidad: el interés público como concepto jurídico. In: Revista española de derecho administrativo. Madri: Civitas, n. 8, pp. 63-94, jan./mar. 1976 (no texto a referência de páginas é da versão eletrônica editada pela Civitas).

PALLIERI, G. Balladore. Diritto costituzionale. 3. ed., Milão: Giuffrè, 1953.

PELLETIER, Christian. L'appreciation de la légalité des actes administratifs par le juge repressif. Paris: LGDJ, 1954.

PEREIRA, André Gonçalves. Erro e ilegalidade no acto administrativo. Lisboa: Ática. 1962.

QUEIRÓ, Afonso Rodrigues. A teoria do "desvio de poder" em direito administrativo. In: Revista de direito administrativo. Rio de Janeiro, v. VI, pp. 41-78, out. 1946.

A teoria do "desvio de poder" em direito administrativo (cont.). In: Revista de direito administrativo. Rio de Janeiro, vol. VII, pp. 52-80, jan./mar. 1947.

Lições de direito administrativo. Coimbra: s/e, 1976, v. I.

RIVERO, Jean. Direito administrativo. Trad. Rogério Ehrhardt Soares. Coimbra: Almedina, 1981.

SANTAMARÍA PASTOR, Juan Alfonso. Renovación dogmática en torno a la desviación de poder como instrumento de control. In: Revista española de derecho administrativo. Madri: Civitas, vl. 2, pp. 303-310, jul./set. 1974 (no texto a referência de páginas é da versão eletrônica editada pela Civitas).

SILVA, José Afonso da. Curso de direito constitucional positivo. 17. ed., São Paulo: Malheiros, 2000.

STASSINOPOULUS, Michel. Traité des actes administratifs. Atenas: Institut Français d'Athènes, 1954.

SUNDFELD, Carlos Ari. Fundamentos de direito público. 2. ed., São Paulo: Malheiros, 1993.

TÁCITO, Caio. Direito administrativo. São Paulo: Saraiva, 1975.

VEDEL, Georges. Droit administratif. Paris: Prèsses Universitaires de France, 1958, t. I.

WALINE, Marcel. Droit administratif. 7. ed., Paris: Sirey, 1957.

ZANCANER, Weida. Da convalidação e da invalidação dos atos administrativos. 2. ed., 2. tir., São Paulo: Malheiros, 1996.

ZANOBINI, Guido. Corso di diritto amministrativo. 8. ed., Milão: Giuffrè, 1958, v. II. 